\title{
Review Article \\ Current and New Approaches in GMO Detection: Challenges and Solutions
}

\author{
Marie-Alice Fraiture, ${ }^{1,2,3}$ Philippe Herman, ${ }^{1}$ Isabel Taverniers, ${ }^{2}$ Marc De Loose, ${ }^{2,4}$ \\ Dieter Deforce, ${ }^{3}$ and Nancy H. Roosens ${ }^{1}$ \\ ${ }^{1}$ Platform of Biotechnology and Molecular Biology (PBB) and Biosafety and Biotechnology Unit (SBB), \\ Scientific Institute of Public Health (WIV-ISP), J. Wytsmanstraat 14, 1050 Brussels, Belgium \\ ${ }^{2}$ Technology and Food Sciences Unit, Institute for Agricultural and Fisheries Research (ILVO), Burg. Van Gansberghelaan 115, \\ Bus 1, 9820 Merelbeke, Belgium \\ ${ }^{3}$ Laboratory of Pharmaceutical Biotechnology, Faculty of Pharmaceutical Sciences, Ghent University, Ottergemsesteenweg 460, \\ 9000 Ghent, Belgium \\ ${ }^{4}$ Department of Plant Biotechnology and Bioinformatics, Faculty of Sciences, Ghent University, Technologiepark 927, \\ 9052 Ghent, Belgium
}

Correspondence should be addressed to Nancy H. Roosens; nancy.roosens@wiv-isp.be

Received 17 July 2015; Accepted 7 September 2015

Academic Editor: Yiannis Kourkoutas

Copyright (C) 2015 Marie-Alice Fraiture et al. This is an open access article distributed under the Creative Commons Attribution License, which permits unrestricted use, distribution, and reproduction in any medium, provided the original work is properly cited.

In many countries, genetically modified organisms (GMO) legislations have been established in order to guarantee the traceability of food/feed products on the market and to protect the consumer freedom of choice. Therefore, several GMO detection strategies, mainly based on DNA, have been developed to implement these legislations. Due to its numerous advantages, the quantitative PCR (qPCR) is the method of choice for the enforcement laboratories in GMO routine analysis. However, given the increasing number and diversity of GMO developed and put on the market around the world, some technical hurdles could be encountered with the qPCR technology, mainly owing to its inherent properties. To address these challenges, alternative GMO detection methods have been developed, allowing faster detections of single GM target (e.g., loop-mediated isothermal amplification), simultaneous detections of multiple GM targets (e.g., PCR capillary gel electrophoresis, microarray, and Luminex), more accurate quantification of GM targets (e.g., digital PCR), or characterization of partially known (e.g., DNA walking and Next Generation Sequencing (NGS)) or unknown (e.g., NGS) GMO. The benefits and drawbacks of these methods are discussed in this review.

\section{Introduction}

With the aim to improve the agricultural practices and nutritional quality, plant breeding techniques have been developed to produce genetically modified (GM) crops expressing interesting traits such as herbicide tolerance, insect resistance, and abiotic stress resistance [1]. To this end, new combinations of their genetic material are created through the use of modern biotechnology [2]. The first genetically modified organism (GMO) approved for the commercialization was the FlavrSavr tomato in 1994. From that time, 181.5 million hectares of planted GM plants in 28 countries were reported in 2014 [1]. Given that the "right to know" for the consumers,
GMO labeling policies have been established in several countries around the world with a threshold of tolerance varying between 0 and $5 \%$. Therefore, the presence of GMO in the food/feed chain is controlled by the competent authorities [3]. To guarantee the GMO traceability, a key factor in the implementation of these regulations, several strategies, categorized as indirect (protein-based methods) or direct (DNA-based methods), have been developed to detect GMO in food/feed samples by using different technologies. Among the protein-based approaches, which target proteins encoded by the transgenes, several methods depend on the EnzymeLinked Immunosorbent Assay (ELISA) technique (Table 1) [4-21]. A portable immunoassay system was also proposed 


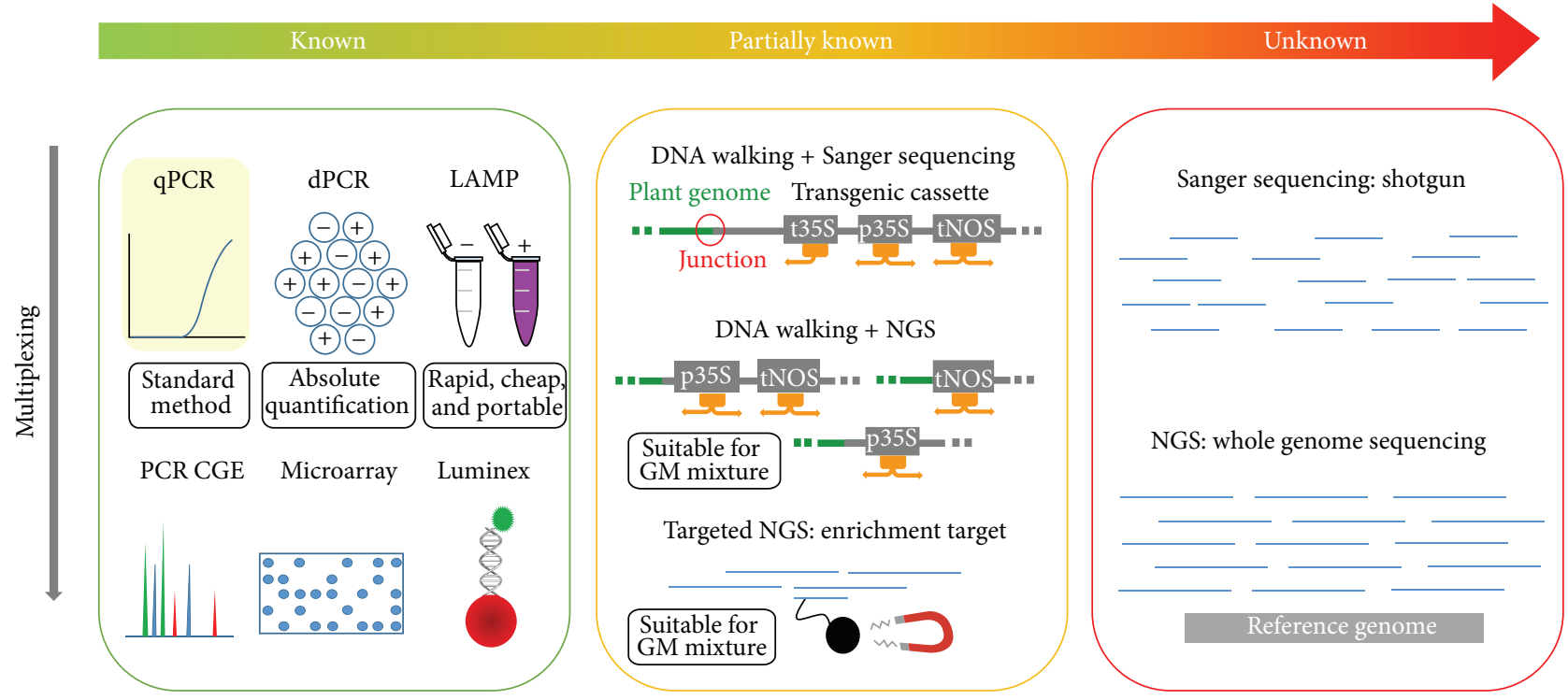

FIGURE 1: Suitable application of GMO detection approaches regarding the adopted strategy as well as the available information about the sequences of tested GMO.

TABLE 1: Representative examples illustrating protein-based methods targeting GMO.

\begin{tabular}{lcc}
\hline Technologies & Targets & References \\
\hline & CP4-EPSPS & {$[4]$} \\
CrylAb & {$[10,12,15,18,20]$} \\
CrylAc & {$[10,14]$} \\
Cry2A & {$[10]$} \\
Cry2Ab & {$[19]$} \\
ELISA & Cry3A & {$[10,16]$} \\
& Cry9C & {$[10]$} \\
& nptII & {$[5,16,22]$} \\
& CP4-EPSPS & {$[6,10,13,22]$} \\
& pat & {$[10,11,13,22]$} \\
Gox & {$[17]$} \\
CpTI & {$[21]$} \\
\hline & CrylAc & {$[23]$} \\
& p35S & {$[24]$} \\
& tNOS & {$[24]$} \\
\hline
\end{tabular}

CP4-EPSPS (5-enolpyruvylshikimate-3-phosphate synthase gene from Agrobacterium tumefaciens strain); CpTI (trypsin inhibitor in cowpea Vigna unguiculata); Cry (gene encoding the Bacillus thuringiensis $\delta$-endotoxin); Gox (glyphosate oxidoreductase gene); nptII (neomycin phosphotransferase II gene); p35S (promoter of the $35 \mathrm{~S}$ cauliflower mosaic virus); tNOS (terminator of the nopaline synthase gene).

(Table 1) [22]. As an alternative, the immuno-PCR method was used to identify GMO (Table 1) [23, 24].

Furthermore, protein-based methods include the use of the mass spectrometry-based technology as a tool allowing characterizing GM crops [25]. However, although they present several advantages such as the rapidity and simplicity, the protein-based methods depend on the expression level of targeted proteins, which is variable according to the plant tissues and the plant developmental status. Moreover, the proteins are highly degraded or denatured by food processing. Any modification in the targeted proteins could indeed alter the specificity and sensitivity of the assay. In addition, this strategy is not applicable if the genetic modification has no impact at the protein level $[26,27]$. To overcome these issues, many DNA-based methods, targeting straightforward transgenic integrated sequences, have been widely developed. Even if quantitative PCR (qPCR) is the method of choice in GMO routine analysis, its inherent PCR properties imply some limitations. Therefore, to address these challenges, some alternative approaches have been developed, allowing notably providing faster detection of GM targets individually amplified in both routine laboratory and field (e.g., loopmediated isothermal amplification (LAMP)), simultaneous detection of several GM targets (e.g., PCR capillary gel electrophoresis (CGE), microarray, and Luminex), more accurate quantification of GM targets (e.g., digital PCR (dPCR)), or characterization of partially known (e.g., DNA walking and Next Generation Sequencing (NGS)) or unknown (e.g., NGS) GMO (Figure 1). These DNA-based approaches and their targets are described in this review. In addition, the most appropriate uses of these approaches are discussed according to the adopted strategy of GMO detection as well as the available information about the sequences of tested GMO.

\section{GMO Detection Approaches}

2.1. qPCR Technology. The qPCR system, which is the most common strategy, allows detecting, identifying, and quantifying GMO via the SYBR Green or TaqMan chemistries (Figure 1) [28]. Using a primer pair specific to the target, these qPCR chemistries are both based on PCR amplification recorded in real time with the fluorescence originated either from the asymmetrical cyanine dye binding to 
double-stranded DNA (SYBR Green) or from the fluorogenic probe specific to the targeted sequence (TaqMan) [29]. This technology is suitable for both unprocessed and processed food/feed matrices since amplicons of around $100 \mathrm{bp}$ are usually amplified. Even if numerous qPCR methods have been reported, three main steps are typically followed in GMO routine analysis [30]. First, the potential presence of GMO is assessed via a screening approach targeting the most common transgenic elements found in GMO, such as p35S (35S promoter from cauliflower mosaic virus) and tNOS (nopaline synthase terminator from Agrobacterium tumefaciens). In addition, some markers more discriminative, such as Cry3Bb, gat-tpinII, and t35S pCAMBIA, and taxon-specific markers could also be used. This step allows establishing a list of the potential GMO present in the tested samples and preventing further unnecessary assays in the subsequent steps (Table 2) [28, 30-34]. Several of these screening markers are validated, based on minimum performance requirements, at the EU level following ring trials and are included in the Compendium of reference methods for GMO analysis [35]. According to the positive and negative signals observed for the different screening markers tested, GM events potentially detected are in a second step identified using constructspecific or event-specific markers targeting, respectively, the junction between two elements inside the transgenic cassette or the junction between the transgenic cassette and the plant genome. In order to properly discriminate each GM event, the event-specific markers are currently favoured since the unique transgenic integration sites are targeted. Finally, the amount of identified GM events present in the tested food/feed samples is determined. Using event-specific and taxon-specific markers, this quantification step is carried out on the basis of the number of copies belonging to the transgene and to the endogen (Table 2) [30]. All the methods used to identify the EU-authorized GMO as well as the GMO for which the authorization is pending or is subjected to be withdrawn in the case of low level presence (LLP) have been provided by the applicants and are reported in the Compendium of reference methods for GMO analysis [35]. In combining several taxon-specific, event-specific, and construct-specific TaqMan markers in a 96-well prespotted plate, a real-time PCR based ready-to-use multitarget analytical system has been developed to allow the simultaneous identification of thirty-nine GM events [36].

In spite of its flexibility, simplicity, rapidity, and high analytical sensitivity, especially crucial to detect a low amount of GM targets, the success of the qPCR strategy depends however on some factors. For instance, the throughput of the qPCR strategy is usually limited to one marker per reaction. Due to the increasing number of GMO, additional markers have continually to be developed and used to fully cover their detection, which could thus make the laboratory work and the analysis of the results quite complex and laborious [32]. In addition, this a priori approach targets only known sequences. Therefore, negative signals guarantee only the absence of known GMO in the tested food/feed samples. Similarly, in case of unexplained signals, in other words, the obtaining of positive and negative signals that found no correspondence with known GM events, the presence of unknown GMO could only be suspected. Indeed, the detection of GMO by qPCR is notably based on transgenic elements originated from natural organisms, such as p35S from CaMV and tNOS from Agrobacterium. For this reason, the qPCR system provides merely an indirect proof of the presence of GMO in a food/feed matrix since it could only be confirmed by the sequence of their transgene flanking regions. Concerning the quantification step, its achievement depends on the availability of Certified Reference Materials (CRM) $[30,33,125]$. Finally, the presence of inhibitors, such as polysaccharides, polyphenols, pectin, xylan, or fat, could alter the efficiency of the PCR reaction. Consequently, a later qPCR signal than theoretically expected will be observed, inducing an underestimation or even concealing the amount of GMO present in the tested sample [126-128].

2.1.1. qPCR Analysis Tools. In order to facilitate the interpretation of results, rapid and cost-efficient systems have been developed via analytical tools integrating simultaneously several targets. To this end, the CoSYPS platform (Combinatory SYBR Green qPCR Screening), which is a decision support system (DSS) at the screening level, has been successfully developed. For each tested food/feed matrix, this DSS combines immediately the experimental $C_{t}$ and $T_{m}$ values obtained with the twenty SYBR Green methods, running in a single 96-well plate and targeting plant gene, taxon genes, and transgenic elements (Table 2). This selection of screening markers allows both covering at least all the EU-authorized GMO and LLP cases (e.g., with p35S and $\mathrm{tNOS}$ ) and, as far as possible, discriminating between themselves and some EU-unauthorized GMO (e.g., with t35S pCAMBIA and gat-tpinII) in order to reduce the number of identifications/quantifications to carry out downstream $[30,33,34,129]$. An alternative to interpret qPCR results is provided by the GMOseek and GMOfinder databases, containing reliable information on GMO. Following the interpretation of the experimental results, obtained with in-house or EU reference methods, the names of positive elements are introduced in the databases to provide a list of potentially detected GMO that will be then experimentally verified $[130,131]$. The truthfulness of these predictions is however diminished since elements identically named can possess different sequences and the detection methods used are not taken into account. Indeed, to target the same element, several methods could exist and could present different PCR efficiencies which could generate variation in the results. Most recently, the JRC-GMO-Matrix platform, combining information from the GMOMETHODS database (all reference methods for GMO analysis) and the Central Core DNA Sequences Information System (several annotated GMO sequences), was also proposed for the same purpose. This platform integrates the positive and negative signals experimentally observed with EU validated taxon-specific, element-specific, construct-specific, and event-specific methods for any tested food/feed matrix in order to predict more reliably the potential amplified GM events [28]. The JRCGMO-Matrix platform is also strengthened by the JRC GMOAmplicons database which contains publically available putative GMO-related sequences [132]. 
TABLE 2: Representative examples illustrating simplex qPCR methods targeting GMO. Those validated at the EU level are indicated by an asterisk. Screening markers used in the CoSYPS are indicated by $\sim$.

\begin{tabular}{|c|c|c|c|c|}
\hline Methods & Chemistries & \multicolumn{2}{|c|}{ Targets } & References \\
\hline \multicolumn{5}{|c|}{ Screening markers } \\
\hline Plant-specific & SYBR Green & \multicolumn{2}{|c|}{$\mathrm{RBCL}^{\sim}$} & [37] \\
\hline \multirow[t]{6}{*}{ Taxon-specific } & SYBR Green & \multicolumn{2}{|c|}{ LEC $^{* \sim}$} & {$[35]$} \\
\hline & SYBR Green & \multicolumn{2}{|c|}{$\mathrm{ADH}^{* \sim}$} & [37] \\
\hline & SYBR Green & \multicolumn{2}{|c|}{$\mathrm{CRU}^{* \sim}$} & [37] \\
\hline & SYBR Green & \multicolumn{2}{|c|}{$\mathrm{PLD}^{\sim}$} & [37] \\
\hline & SYBR Green & \multicolumn{2}{|c|}{$\mathrm{SAD1}^{\sim}$} & {$[35]$} \\
\hline & SYBR Green & \multicolumn{2}{|c|}{$\mathrm{GLU}^{\sim}$} & {$[35]$} \\
\hline \multirow[t]{18}{*}{ Element-specific } & SYBR Green & \multicolumn{2}{|c|}{ p35S $\mathrm{S}^{* \sim}$} & {$[31]$} \\
\hline & TaqMan & \multicolumn{2}{|c|}{ p35S* } & {$[38]$} \\
\hline & SYBR Green & \multicolumn{2}{|c|}{ tNOS* } & [31] \\
\hline & TaqMan & \multicolumn{2}{|c|}{$\mathrm{tNOS}^{*}$} & {$[38]$} \\
\hline & SYBR Green & \multicolumn{2}{|c|}{$\mathrm{pFMV}^{\sim}$} & [39] \\
\hline & TaqMan & \multicolumn{2}{|c|}{$\mathrm{pFMV}^{*}$} & {$[35]$} \\
\hline & SYBR Green & \multicolumn{2}{|c|}{$\mathrm{pNOS}^{\sim}$} & [39] \\
\hline & SYBR Green & \multicolumn{2}{|c|}{$\mathrm{t} 35 \mathrm{~S}^{\sim}$} & In-house \\
\hline & SYBR Green & \multicolumn{2}{|c|}{ CrylAb/Ac ${ }^{\sim}$} & {$[40]$} \\
\hline & TaqMan & \multicolumn{2}{|c|}{ CrylA(b) ${ }^{*}$} & {$[35]$} \\
\hline & SYBR Green & \multicolumn{2}{|c|}{$\mathrm{Cry}_{3 \mathrm{Bb}} \sim$} & {$[34]$} \\
\hline & SYBR Green & & & {$[40]$} \\
\hline & TaqMan & & & {$[35]$} \\
\hline & SYBR Green & & & {$[40]$} \\
\hline & TaqMan & & & {$[35]$} \\
\hline & SYBR Green & $\mathrm{CP} 4$ & & {$[40]$} \\
\hline & SYBR Green & $\mathrm{t} 35 \mathrm{~S} p$ & & {$[33]$} \\
\hline & SYBR Green & & & {$[35]$} \\
\hline Construct-specific & SYBR Green & gat & & {$[34]$} \\
\hline Virus-specific & SYBR Green & & & In-house \\
\hline & & vent-specific methods & & \\
\hline GM-specific & TaqMan & Maize (Zea mays) & $3272^{*}$ & {$[35]$} \\
\hline & TaqMan & Maize (Zea mays) & $5307^{*}$ & {$[35]$} \\
\hline & TaqMan & Maize (Zea mays) & $98140^{*}$ & {$[35]$} \\
\hline & TaqMan & Maize (Zea mays) & Bt11* & {$[35]$} \\
\hline & TaqMan & Maize (Zea mays) & Bt176* & {$[35]$} \\
\hline & TaqMan & Maize (Zea mays) & DAS-40278-9* & {$[35]$} \\
\hline & TaqMan & Maize (Zea mays) & DAS-59122-7* & {$[35]$} \\
\hline & TaqMan & Maize (Zea mays) & GA $21^{*}$ & {$[35]$} \\
\hline & TaqMan & Maize (Zea mays) & LY038* & {$[35]$} \\
\hline & TaqMan & Maize (Zea mays) & MIR162* & {$[35]$} \\
\hline & TaqMan & Maize (Zea mays) & MIR604* & {$[35]$} \\
\hline & TaqMan & Maize (Zea mays) & MON810* & {$[35]$} \\
\hline & TaqMan & Maize (Zea mays) & MON863* & {$[35]$} \\
\hline & TaqMan & Maize (Zea mays) & MON87460* & {$[35]$} \\
\hline & TaqMan & Maize (Zea mays) & MON88017* & {$[35]$} \\
\hline & TaqMan & Maize (Zea mays) & MON89034* & {$[35]$} \\
\hline & TaqMan & Maize (Zea mays) & NK603* & {$[35]$} \\
\hline & TaqMan & Maize (Zea mays) & $\mathrm{T} 25^{*}$ & {$[35]$} \\
\hline & TaqMan & Maize (Zea mays) & $\mathrm{TC} 1507^{*}$ & {$[35]$} \\
\hline & TaqMan & Soybean (Glycine max) & A2704-12* & {$[35]$} \\
\hline
\end{tabular}


TABLE 2: Continued.

\begin{tabular}{|c|c|c|c|c|}
\hline \multirow[t]{2}{*}{ Methods } & \multirow{2}{*}{$\begin{array}{c}\text { Chemistries } \\
\text { TaqMan }\end{array}$} & \multicolumn{2}{|c|}{ Targets } & \multirow{2}{*}{$\begin{array}{c}\text { References } \\
35]\end{array}$} \\
\hline & & Soybean (Glycine max) & A5547-127* & \\
\hline & TaqMan & Soybean (Glycine max) & BPS-CV-127* & {$[35]$} \\
\hline & TaqMan & Soybean (Glycine max) & DAS68416-4* & {$[35]$} \\
\hline & TaqMan & Soybean (Glycine max) & DP-305423-1* & {$[35]$} \\
\hline & TaqMan & Soybean (Glycine max) & DP-356043-5* & {$[35]$} \\
\hline & TaqMan & Soybean (Glycine max) & FG72* & [35] \\
\hline & TaqMan & Soybean (Glycine max) & GTS40-3-2* & {$[35]$} \\
\hline & TaqMan & Soybean (Glycine max) & MON87701* & [35] \\
\hline & TaqMan & Soybean (Glycine max) & MON87705* & {$[35]$} \\
\hline & TaqMan & Soybean (Glycine max) & MON87708* & [35] \\
\hline & TaqMan & Soybean (Glycine max) & MON87769* & {$[35]$} \\
\hline & TaqMan & Soybean (Glycine max) & MON89788* & [35] \\
\hline & TaqMan & Cotton (Gossypium hirsutum) & $281-24-236^{*}$ & [35] \\
\hline & TaqMan & Cotton (Gossypium hirsutum) & $3006-210-23^{*}$ & [35] \\
\hline & TaqMan & Cotton (Gossypium hirsutum) & GHB119* & [35] \\
\hline & TaqMan & Cotton (Gossypium hirsutum) & $\mathrm{GHB} 614^{*}$ & {$[35]$} \\
\hline & TaqMan & Cotton (Gossypium hirsutum) & LLCOTTON25* & {$[35]$} \\
\hline & TaqMan & Cotton (Gossypium hirsutum) & MON531* & {$[35]$} \\
\hline & TaqMan & Cotton (Gossypium hirsutum) & MON1445* & {$[35]$} \\
\hline & TaqMan & Cotton (Gossypium hirsutum) & MON15985* & [35] \\
\hline & TaqMan & Cotton (Gossypium hirsutum) & MON88913* & [35] \\
\hline & TaqMan & Cotton (Gossypium hirsutum) & $\mathrm{T} 304-40^{*}$ & [35] \\
\hline & TaqMan & Oilseed rape (Brassica napus) & $73496^{*}$ & [35] \\
\hline & TaqMan & Oilseed rape (Brassica napus) & $\mathrm{GT}^{*} 3^{*}$ & [35] \\
\hline & TaqMan & Oilseed rape (Brassica napus) & MON88302* & {$[35]$} \\
\hline & TaqMan & Oilseed rape (Brassica napus) & $\mathrm{Msl}^{*}$ & {$[35]$} \\
\hline & TaqMan & Oilseed rape (Brassica napus) & Ms8* & {$[35]$} \\
\hline & TaqMan & Oilseed rape (Brassica napus) & $\mathrm{Rf1}^{*}$ & [35] \\
\hline & TaqMan & Oilseed rape (Brassica napus) & $\mathrm{Rf}^{*}$ & [35] \\
\hline & TaqMan & Oilseed rape (Brassica napus) & $\mathrm{Rf}^{*}$ & {$[35]$} \\
\hline & TaqMan & Oilseed rape (Brassica napus) & $\mathrm{T} 45^{*}$ & [35] \\
\hline & TaqMan & Oilseed rape (Brassica napus) & Topas $19 / 2^{*}$ & {$[35]$} \\
\hline & TaqMan & Potato (Solanum tuberosum) & EH92-527-1* & [35] \\
\hline & TaqMan & Rice (Oryza sativa) & LLRICE62* & {$[35]$} \\
\hline & TaqMan & Sugar beet (Beta vulgaris) & $\mathrm{H} 7-1^{*}$ & [35] \\
\hline
\end{tabular}

$\mathrm{ADH}$ (alcohol dehydrogenase I gene from maize); bar (phosphinothricin-N-acetyltransferases gene from Streptomyces hygroscopicus); CP4-EPSPS (5enolpyruvylshikimate-3-phosphate synthase gene from Agrobacterium tumefaciens strain); CRT (reverse transcriptase gene from the cauliflower mosaic virus); CRU (cruciferin gene from colza); Cry (gene encoding the Bacillus thuringiensis $\delta$-endotoxin); gat-tpinII (junction sequence between the glyphosate Nacetyltransferase of Bacillus licheniformis and the terminator of the Solanum tuberosum proteinase inhibitor); GLU (glutamine synthetase gene from sugar beet); LEC (lectin gene from soybean); nptII (neomycin phosphotransferase II gene); p35S (promoter of the 35 S cauliflower mosaic virus); pat (phosphinothricin$\mathrm{N}$-acetyltransferases gene from Streptomyces viridochromogenes); pFMV (promoter of the figwort mosaic virus); phy (phytase gene from maize); PLD (phospholipase D gene from rice); pNOS (promoter of the nopaline synthase gene); RBCL (ribulose-1,5-biphosphate carboxylase oxygenase); SAD1 (stearoylacyl carrier protein desaturase gene from cotton); t35S (terminator of the cauliflower mosaic virus); t35S pCAMBIA (terminator of the cauliflower mosaic virus from PCAMBIA vector); tNOS (terminator of the nopaline synthase gene).

2.1.2. Multiplex qPCR Strategy. With multiplex PCR-based methods, several DNA targets can be detected in a single reaction. It presents the advantage to decrease the number of reactions necessary to test the potential presence of GMO in a sample. Several multiplex qPCR TaqMan strategies have thus been investigated, including mainly the screening markers p35S and tNOS (Table 3) [38, 41, 43-49]. To provide a system with a high GMO coverage, twenty-three triplex and one duplex PCR were gathered on a 384-well plate to identify forty-seven targets (Table 3) [42].

However, compared to simplex qPCR, the development of optimal multiplex assays could be more challenging notably in terms of primers and probes design as well as sensitivity and reproducibility. Moreover, the throughput of this strategy is relatively limited by the availability of dyes with an emission and absorption spectrum of fluorescence sufficiently distinct 
TABLE 3: Representative examples illustrating multiplex qPCR TaqMan methods targeting GMO. Those validated at the EU level are indicated by an asterisk.

\begin{tabular}{|c|c|c|c|}
\hline Multiplexing & Methods & Targets & References \\
\hline Duplex & Element-specific & $\mathrm{p} 35 \mathrm{~S}^{*}$ and $\mathrm{tNOS}^{*}$ & [38] \\
\hline Duplex & Element-specific & bar and pat & {$[41]$} \\
\hline \multirow{2}{*}{ Duplex } & Plant-specific & TLC & \multirow{2}{*}[42]{} \\
\hline & Other & IPC & \\
\hline \multirow{2}{*}{ Duplex } & Taxon-specific & $\mathrm{ADH}$ & \multirow{2}{*}[43]{} \\
\hline & Event-specific & Bt11 & \\
\hline \multirow{2}{*}{ Duplex } & Taxon-specific & $\mathrm{ADH}$ & \multirow{2}{*}[43]{} \\
\hline & Event-specific & Bt176 & \\
\hline \multirow{2}{*}{ Duplex } & Taxon-specific & $\mathrm{ADH}$ & \multirow{2}{*}[43]{} \\
\hline & Event-specific & MON810 & \\
\hline \multirow{2}{*}{ Duplex } & Taxon-specific & $\mathrm{ADH}$ & \multirow{2}{*}[43]{} \\
\hline & Event-specific & $\mathrm{T} 25$ & \\
\hline Triplex & Element-specific & p35S, tNOS, and CTP2/CP4-EPSPS & {$[41]$} \\
\hline \multirow{2}{*}{ Triplex } & Taxon-specific & LEC and Zein & \multirow[t]{2}{*}[42]{} \\
\hline & Other & IPC & \\
\hline \multirow{2}{*}{ Triplex } & Taxon-specific & Pro and PC & \multirow{2}{*}[42]{} \\
\hline & Other & IPC & \\
\hline \multirow{2}{*}{ Triplex } & Taxon-specific & ACC and FRUp & \multirow[t]{2}{*}[42]{} \\
\hline & Other & IPC & \\
\hline \multirow{2}{*}{ Triplex } & Taxon-specific & SAD1 and FRUt & \multirow{2}{*}[42]{} \\
\hline & Other & IPC & \\
\hline \multirow{2}{*}{ Triplex } & Element-specific & p35S and pFMV & \multirow{2}{*}[42]{} \\
\hline & Other & IPC & \\
\hline \multirow{2}{*}{ Triplex } & Element-specific & tE9 and tNOS & \multirow[t]{2}{*}[42]{} \\
\hline & Other & IPC & \\
\hline Triplex & Element-specific & bar and CP4-EPSPS & {$[42]$} \\
\hline & Other & IPC & \\
\hline Triplex & Element-specific & hpt and pat & {$[42]$} \\
\hline & Other & IPC & \\
\hline Triplex & Element-specific & nptII and CrylAb/Ac & [42] \\
\hline & Other & IPC & \\
\hline Triplex & Construct-specific & CBH351 and Bt176 & [42] \\
\hline 11рта & Other & IPC & \\
\hline Triplex & Construct-specific & MON810 and T25 & {$[42]$} \\
\hline & Other & IPC & \\
\hline Triplex & Construct-specific & Bt11 and MON863 & {$[42]$} \\
\hline & Other & IPC & \\
\hline Triplex & Construct-specific & NK603 and GA21 & [42] \\
\hline & Other & IPC & \\
\hline Triplex & Construct-specific & TC1507 and DAS-59122-7 & [42] \\
\hline & Other & IPC & \\
\hline Triplex & Construct-specific & MIR604 and MON88017 & [42] \\
\hline & Other & IPC & \\
\hline Triplex & Construct-specific & 98140 and MON89034 & {$[42]$} \\
\hline & Other & IPC & \\
\hline Triplex & Construct-specific & 3272 and MIR162 & {$[42]$} \\
\hline & Other & IPC & \\
\hline Triplex & Construct-specific & A2704-12 and GTS40-3-2 & [42] \\
\hline 111ріех & Other & IPC & \\
\hline
\end{tabular}


TABLE 3: Continued.

\begin{tabular}{|c|c|c|c|}
\hline Multiplexing & Methods & Targets & References \\
\hline \multirow{2}{*}{ Triplex } & Construct-specific & DP-305423-1 and DP-356043-5 & \multirow{2}{*}[42]{} \\
\hline & Other & IPC & \\
\hline \multirow{2}{*}{ Triplex } & Construct-specific & MON87701 and MON89788 & \multirow{2}{*}[42]{} \\
\hline & Other & IPC & \\
\hline \multirow{3}{*}{ Triplex } & Element-specific & AHAS & \multirow{2}{*}[42]{} \\
\hline & Construct-specific & FG72 & \\
\hline & Other & IPC & {$[42]$} \\
\hline \multirow{2}{*}{ Triplex } & Construct-specific & Bt63 and A5547-127 & \multirow{2}{*}[42]{} \\
\hline & Other & IPC & \\
\hline \multirow{3}{*}{ Triplex } & Element-specific & $\mathrm{Xa} 21$ & \multirow{5}{*}[44]{} \\
\hline & Construct-specific & KMD1 & \\
\hline & Other & IPC & \\
\hline \multirow{2}{*}{ Triplex } & Taxon-specific & Zein & \\
\hline & Construct-specific & MON810 and GA21 & \\
\hline \multirow{2}{*}{ Triplex } & Taxon-specific & $\mathrm{ADH}$ & \multirow{2}{*}[44]{} \\
\hline & Construct-specific & MON810 and GA21 & \\
\hline Triplex & Element-specific & $\mathrm{p} 35 \mathrm{~s}, \mathrm{tNOS}$, and $\mathrm{t} 35 \mathrm{~S}$ & {$[45]$} \\
\hline Triplex & Element-specific & tE9, pRbcS4, and tORF23 & {$[45]$} \\
\hline \multirow{2}{*}{ Triplex } & Element-specific & tpinII and tAHASL & \multirow{2}{*}[45]{} \\
\hline & Event-specific & DP-305423-1 & \\
\hline Tetraplex & Element-specific & pFMV, bar, pat, and CTP2/CP4-EPSPS & [46] \\
\hline Tetraplex & Element-specific & p35S, tNOS, pFMV, and bar & \multirow[t]{2}{*}[47]{} \\
\hline \multirow{3}{*}{ Pentaplex } & Taxon-specific & HMG and LEC & \\
\hline & Element-specific & $\mathrm{p} 35 \mathrm{~S}$ and $\mathrm{tNOS}$ & \multirow[t]{2}{*}[46]{} \\
\hline & Virus-specific & CaMV & \\
\hline Pentaplex & Element-specific & p35S, tNOS, bar, pat, and CTP2/CP4-EPSPS & [41] \\
\hline \multirow{2}{*}{ Pentaplex } & Taxon-specific & LEC & \multirow[t]{2}{*}[48]{} \\
\hline & Event-specific & MON87769, MON87708, MON87705, and FG72 & \\
\hline \multirow{3}{*}{ Hexaplex } & Element-specific & p35S, tNOS, and pFMV & \multirow{3}{*}{ [49] } \\
\hline & Construct-specific & SAMS and LY & \\
\hline & Other & IPC & \\
\hline
\end{tabular}

ACC (acetyl-CoA-carboxylase gene from colza); ADH (alcohol dehydrogenase I gene from maize); AHAS (AHAS fragment unique recombination from BPS-CV-127); bar (phosphinothricin-N-acetyltransferases gene from Streptomyces hygroscopicus); CaMV (ORFIII from CaMV); CP4-EPSPS (5enolpyruvylshikimate-3-phosphate synthase gene from Agrobacterium tumefaciens strain); Cry (gene encoding the Bacillus thuringiensis $\delta$-endotoxin); CTP2/CP4-EPSP (junction region between the chloroplast transit peptide 2 (CTP2) sequence from the Arabidopsis thaliana epsps gene and the CP4 epsps gene from Agrobacterium tumefaciens (CP4-EPSPS)); FRUp ( $\beta$-fructosidase gene from potato); FRUt ( $\beta$-fructosidase gene from tomato); HMG (major highmobility group protein gene from maize); hpt (hygromycin phosphotransferase gene); IPC (internal positive control); LEC (lectin gene from soybean); LS28 (choline kinase); LY (transition from Zea mays chloroplast transit peptide sequence for dihydrodipicolinate synthase to Corynebacterium glutamicum dihydrodipicolinate synthase (cordapA) gene encoding for a lysine-insensitive dihydrodipicolinate synthase enzyme); nptII (neomycin phosphotransferase II gene); p35S (promoter of the $35 \mathrm{~S}$ cauliflower mosaic virus); pat (phosphinothricin-N-acetyltransferases gene from Streptomyces viridochromogenes); PC (phosphoenolpyruvate carboxylase gene from wheat); pFMV (promoter of the figwort mosaic virus); pRbcS4 (ribulose 1,5-bisphosphate carboxylase small subunit promoter from A. thaliana); Pro (prolamin gene from rice); SAD1 (stearoyl-acyl carrier protein desaturase gene from cotton); SAMS (transition from S-adenosyl-L-methionine synthetase (SAMS) promoter to Glycine max acetolactate synthase (gm-hra) gene); t35S (terminator of the cauliflower mosaic virus); tAHASL (acetohydroxy acid synthase large subunit terminator from A. thaliana); tE9 (ribulose-1,5-bisphosphate carboxylase terminator E9 from Pisum sativum); TLC (tRNA-Leu chloroplastic gene); tNOS (terminator of the nopaline synthase gene); tORF23 (open reading frame 23 terminator from A. tumefaciens); tpinII (inhibitor II terminator from potato); Zein (Zein gene from maize), Xa21 (Xa21 gene from Oryza longistaminata).

to avoid overlaps of signals. The combination of different dyes risks also increases the fluorescent background. Therefore, the majority of the reported multiplex qPCR assays amplify simultaneously only two or three targets. To date, a maximum of six markers have been successfully combined in one reaction to detect GMO $[35,49]$.
2.2. Alternative Multiplex Strategies. Still with the aim of going further in the development of multiplex assays, several methods not based on qPCR have been also developed using notably the CGE, microarray, and Luminex technologies. Two main steps are generally followed. Firstly, to guarantee a sufficient sensitivity, the samples are amplified by PCR since 
TABLE 4: Representative examples illustrating multiplex PCR CGE methods targeting GMO.

\begin{tabular}{lcll}
\hline Multiplexing & Methods & Targets & References \\
\hline \multirow{2}{*}{ Tetraplex } & Taxon-specific & Zein and LEC \\
& Element-specific & p35S and tNOS \\
Tetraplex & Taxon-specific & SAD1 \\
& Element-specific & CrylAc, p35S, and tNOS \\
Pentaplex & Taxon-specific & ADH & [50] \\
& Event-specific & Bt11, GA21, MON810, and NK603 \\
Hexaplex & Taxon-specific & acp1 \\
& Event-specific & Bollgard, Bollgard II, RR, 3006-210-23, and 281-24-231 \\
Hexaplex & Taxon-specific & HMG \\
& Event-specific & DAS-59122-7, LY038, MON88017, MIR604, and 3272 \\
Octaplex & Event-specific & Bt11, Bt176, Huanong No. 1, GTS40-3-2, T25, MON88913, MON1445, and MIR604 \\
& Taxon-specific & LEC and ssIIb \\
Octaplex & Element-specific & pFMV and tNOS \\
& Event-specific & TC1507, MON531, NK603, and GA21 \\
& Taxon-specific & SAD1 \\
Ectaplex & Element-specific & bar, chy, pAct, CP4-EPSPS, and CrylAb \\
& Event-specific & GT73 and OXY235 \\
Nonaplex & Taxon-specific & HMG \\
\hline
\end{tabular}

acp1 (acyl carrier protein 1 gene from cotton); ADH (alcohol dehydrogenase I gene from maize); bar (phosphinothricin-N-acetyltransferases gene from Streptomyces hygroscopicus); Chy (chymopapain gene from papaya); CP4-EPSPS (5-enolpyruvylshikimate-3-phosphate synthase gene from Agrobacterium tumefaciens strain); Cry (gene encoding the Bacillus thuringiensis $\delta$-endotoxin); HMG (major high-mobility group protein gene from maize); LEC (lectin gene from soybean); p35S (promoter of the $35 \mathrm{~S}$ cauliflower mosaic virus); pAct (promoter region of rice actin gene); pFMV (promoter of the figwort mosaic virus); SAD1 (stearoyl-acyl carrier protein desaturase gene from cotton); ssIIb (starch synthase IIb gene from maize); tNOS (terminator of the nopaline synthase gene); Zein (Zein gene from maize).

the GM targets are potentially at trace level in food/feed matrices. In a second step, the PCR products are analyzed using the CGE, microarray, or Luminex platforms. Despite the fact that these technologies present a higher throughput than $\mathrm{qPCR}$, their multiplexing level is still influenced by the inherent properties of PCR which limit the number of reactions at commonly ten targets per PCR assay $[133,134]$.

2.2.1. PCR Capillary Gel Electrophoresis Technology. In order to detect simultaneously several targets, the use of the PCR multiplex CGE, where fluorescently labelled primers allow discriminating different amplicons of the same size, has been also suggested to be applied in the GMO detection field (Figure 1 and Table 4). Compared to the electrophoresis gel, the resolution power of the CGE system to detect PCR products from a multiplex assay is clearly higher [134]. However, the sensitivity of CGE system is weaker than the qPCR technology [135]. Using the PCR CGE system, eight GM maize were identified via a nonaplex PCR including event-specific, construct-specific, and taxon-specific methods (Table 4) [57, 58]. Similarly, one pentaplex PCR and two hexaplex PCR were also developed to, respectively, detect specifically four GM maize, five GM cotton, and five GM maize (Table 4) [52-55]. Recently, a tetraplex targeting transgenic elements and cotton-specific gene was also reported (Table 4) [51]. In addition, Guo et al., 2011 developed three octaplex PCR using universally tailed primers to preamplify GM targets under a short number of cycles. To increase the yield and
PCR efficiency, these amplicons, earlier submitted to a PCR emulsion, are then enriched with universal primers. By this way, twenty-four targets from fourteen GM events were identified by the CGE system (Table 4) [56]. A variant of this technique, which implies no fluorescent labels on primers, is reported by Burrell et al., 2011. This study proposed a tetraplex PCR composed of two species-specific methods and two screening markers allowing detecting the presence of Bt11 maize and GTS40-3-2 soybean events using commercialized electrophoresis instruments (Table 4) [50].

2.2.2. Microarrays Technology. With the microarray technology applied to GMO detection, GM targets are amplified by PCR, using target-specific and/or universal primers, prior to being hybridized on the array, allowing the simultaneous detection of more than 250000 targets in one assay (Figure 1 and Table 5) [136]. Compared to the qPCR, the microarray strategy presents thus a well higher throughput but a slightly weaker sensitivity $[133,137]$. One approach, called multiplex quantitative DNA array-based PCR (MQDA-PCR), tested on transgenic maize events, consists of a first PCR using target-specific primers that harbor a universal tail allowing using universal primers in the second PCR. The signal is then detected after the hybridization of the PCR products with the fluorescently labelled probes on the DNA array (Table 5) [63]. Furthermore, using a padlock probe ligationmicroarray detection system (PPLMD), some GM maize, cotton, and soybean events were detected. With the PPLMD 
TABLE 5: Representative examples illustrating multiplex PCR microarray methods targeting GMO.

\begin{tabular}{|c|c|c|c|c|}
\hline Multiplexing & Techniques & Methods & Targets & References \\
\hline Duplex & DualChip GMO & Element-specific & p35S and tNOS & [59-61] \\
\hline \multirow{2}{*}{ Duplex } & \multirow{2}{*}{ DualChip GMO } & Construct-specific & pNOS/nptII & \multirow{2}{*}{ [59-61] } \\
\hline & & Virus-specific & CaMV & \\
\hline Triplex & DualChip GMO & Element-specific & pat, CrylA(b), and CP4-EPSPS & [59-61] \\
\hline \multirow{2}{*}{ Triplex } & \multirow{2}{*}{ NAIMA } & Taxon-specific & IVR & \multirow{2}{*}[62]{} \\
\hline & & Element-specific & p35S and tNOS & \\
\hline \multirow{3}{*}{ Triplex } & \multirow{3}{*}{ NAIMA } & Taxon-specific & IVR & \multirow{3}{*}[62]{} \\
\hline & & Element-specific & p35S & \\
\hline & & Event-specific & MON810 & \\
\hline \multirow{2}{*}{ Tetraplex } & \multirow{2}{*}{ DualChip GMO } & Plant-specific & $\mathrm{RBCL}$ & \multirow{6}{*}{$\begin{array}{c}{[59-61]} \\
{[63]}\end{array}$} \\
\hline & & Taxon-specific & IVR, LEC, and CRU & \\
\hline \multirow{4}{*}{ Octaplex } & \multirow{4}{*}{ MQDA-PCR } & Taxon-specific & HMG & \\
\hline & & Element-specific & $\mathrm{p} 35 \mathrm{~S}$ and $\mathrm{tNOS}$ & \\
\hline & & Event-specific & Bt176, Bt11, and MON810 & \\
\hline & & other & IPC & \\
\hline \multirow{3}{*}{ Decaplex } & \multirow{3}{*}{ PPLMD } & Taxon-specific & SAD1, Zein, ACC, and LEC & \multirow{3}{*}[64]{} \\
\hline & & Element-specific & p35S, pFMV, and bar & \\
\hline & & Event-specific & MON1445, Bt176, and GTS40-3-2 & \\
\hline \multirow{4}{*}{ Dodecaplex } & \multirow{4}{*}{ MQDA-PCR } & Taxon-specific & HMG & \multirow{4}{*}{ [63] } \\
\hline & & Element-specific & p35S, tNOS, and Amp & \\
\hline & & Event-specific & Bt176, Bt11, MON810, T25, GA21, CBH351, and DBT418 & \\
\hline & & Other & IPC & \\
\hline
\end{tabular}

ACC (acetyl-CoA-carboxylase gene from colza); Amp (ampicillin resistance gene); bar (phosphinothricin-N-acetyltransferases gene from Streptomyces hygroscopicus); CaMV (ORFIII from CaMV); CP4-EPSPS (5-enolpyruvylshikimate-3-phosphate synthase gene from Agrobacterium tumefaciens strain); CRU (cruciferin gene from colza); Cry (gene encoding the Bacillus thuringiensis $\delta$-endotoxin); HMG (major high-mobility group protein gene from maize); IPC (internal positive control); IVR (invertase gene from maize); LEC (lectin gene from soybean); nptII (neomycin phosphotransferase II gene); p35S (promoter of the $35 \mathrm{~S}$ cauliflower mosaic virus); pat (phosphinothricin-N-acetyltransferases gene from Streptomyces viridochromogenes); pFMV (promoter of the figwort mosaic virus); pNOS (promoter of the nopaline synthase gene); RBCL (ribulose-1,5-biphosphate carboxylase oxygenase); SAD1 (stearoyl-acyl carrier protein desaturase gene from cotton); tNOS (terminator of the nopaline synthase gene); Zein (Zein gene from maize).

system, the targets are initially hybridized to linear padlock probes harboring target-specific and universal sequences to be then amplified by PCR with universal primers (Table 5) [64]. In addition, a nucleic acid sequence based amplification implemented microarray (NAIMA) approach, using universal primers, has been tested on transgenic maize (Table 5) $[62,137]$. As an alternative to the potential issue related to the use of fluorescent label, the DualChip GMO system was proposed. So, after PCR amplification with biotinylated targetspecific primers, the amplicons hybridized on the arrays are detected by a colorimetric reaction, allowing identifying simultaneously some GM maize, soybean, and rapeseed events. The performance of the DualChip GMO system, targeting fourteen elements, was also validated through an EU collaborative ring trial. An upgraded version of this system (DualChip GMO V2.0) presents a higher GMO coverage in targeting thirty elements (Table 5) [59-61, 133, 138]. Most recently, a multiplex amplification on a chip with readout on an oligo microarray (MACRO) system, targeting ninety-one targets to cover a broad spectrum of GMO, was also reported [139].

2.2.3. Luminex Technology. Biotinylated targets amplified by single or multiplex PCR assays could be analyzed with the Luminex technology, potentially able to simultaneously detect up to 500 different targets in one sample using spectrally distinct sets of beads that are independently coupled to unique nucleic acid probes. After hybridization of biotinylated oligonucleotides to corresponding probebead complexes, the reader device individually analyzes each microsphere by flow cytometry in applying a laser excitation of $635 \mathrm{~nm}$ and $532 \mathrm{~nm}$ allowing, respectively, identifying the bead set and determining the presence or absence of the target (Figure 1) [140]. This technology was firstly assessed in GMO detection by Fantozzi et al., 2008 (Table 6). In this study, the p35S and EPSPS elements, earlier individually amplified by PCR from the GTS-40-3-2 soybean event, were simultaneously detected [65]. Afterwards, the GM stacked LS28 $\times$ CrylAc rice and 281-24-236 × 3006-210-23 cotton events were identified on the Luminex platform using upstream, respectively, a pentaplex PCR or a hexaplex PCR (Table 6) $[67,68]$. This technology was also used to detect ten GM maize events through four sets of multiplex PCR assays (Table 6) [66]. Similarly, a liquid bead array approach allowing identifying thirteen GM maize was recently developed [141].

Due to its potential high throughput, the Luminex technology seems to be a promising alternative in GMO 
TABLE 6: Representative examples illustrating Luminex strategies targeting GMO.

\begin{tabular}{|c|c|c|c|}
\hline Multiplexing & Methods & Targets & References \\
\hline Simplex & Element-specific & p35S and CP4-EPSPS & {$[65]$} \\
\hline \multirow{2}{*}{ Triplex } & Taxon-specific & Zein & \multirow{2}{*}[66]{} \\
\hline & Event-specific & MIR604 and MON88017 & \\
\hline Tetraplex & Event-specific & Bt176, MON810, NK603, and GA21 & {$[66]$} \\
\hline Tetraplex & Event-specific & Bt11, T25, MIR162, and MON89034 & {$[66]$} \\
\hline \multirow{2}{*}{ Pentaplex } & Taxon-specific & SPS & \multirow{3}{*}[67]{} \\
\hline & Element-specific & CrylAc, tNOS, p35S, and LS28 & \\
\hline \multirow{3}{*}{ Hexaplex } & Taxon-specific & SAD1 & \\
\hline & Element-specific & CrylAc, CrylF, and pat & \multirow[t]{2}{*}[68]{} \\
\hline & Event-specific & 281-24-236 and 3006-210-23 & \\
\hline
\end{tabular}

CP4-EPSPS (5-enolpyruvylshikimate-3-phosphate synthase gene from Agrobacterium tumefaciens strain); Cry (gene encoding the Bacillus thuringiensis $\delta$ endotoxin); LS28 (choline kinase); p35S (promoter of the $35 \mathrm{~S}$ cauliflower mosaic virus) SAD1 (stearoyl-acyl carrier protein desaturase gene from cotton); SPS (sucrose phosphate synthase gene from rice); tNOS (terminator of the nopaline synthase gene); tORF23 (open reading frame 23 terminator from A. tumefaciens); Zein (Zein gene from maize).

detection. Moreover, the liquid bead array is considered as more sensitive and faster than the microarray system [67]. Nevertheless, the drawback linked to the PCR complicates the setting of a unique multiplex assay targeting simultaneously all GM events. Furthermore, as only few studies using this technology in GMO detection have been reported to date, experiments have still to be carried out in order to provide effective and validated systems.

2.3. Digital PCR Technology. To resolve difficulties observed during the relative quantification step in qPCR, especially when the copy numbers of GMO are low and/or PCR inhibitors are present, the digital PCR (dPCR) technology has been tested in GMO detection (Figure 1). Based on the binomial Poisson statistics, each partition of the fractionated sample is determined as positive (amplified target observed) or negative (no amplified target observed) by the dPCR technology allowing absolutely quantifying the number of nucleic acid targets from GMO present in any given sample. Two approaches of this end-point PCR system have up till now been used for this aim (Table 7). On the one hand, the chamber dPCR (cdPCR), partitioning the sample in several thousands of microfluidic chambers, was used to target GM maize MON810 event using a duplex PCR composed of the MON810 event-specific and maize taxon-specific methods. The detection limits of this approach were also investigated [72-74]. Moreover, a strategy based on the cdPCR system was developed in order to cover a wide range of GMO by applying individually twenty-eight element-specific, thirty-six eventspecific, and five taxon-specific methods (Table 7) [69]. Afterwards, this strategy was applied with forty-eight markers, including seven transgenic elements-specific, fourteen event-specific, and five taxon-specific methods (Table 7) [70]. On the other hand, the droplet dPCR (ddPCR) approach, implying several thousands of droplets generated by a wateroil emulsion, was used in simplex or duplex PCR with the MON810 event-specific and maize taxon-specific methods [71]. Most recently, duplex assays, including one GMOspecific marker with one soybean, maize, or rice taxonspecific marker, were performed by using the ddPCR system to quantify twelve GM soybean, sixteen GM maize, and two GM rice events (Table 7) $[48,75]$.

The dPCR technology could become a key tool in the field of GMO detection, mainly because an absolute, and not relative as in qPCR, quantification of the GM target is provided. The measurement does not require necessarily the use of reference material, solving issues related to the availability of an optimal reference material. Moreover, thanks to the partitioning of the sample, the PCR efficiency is less affected by the presence of inhibitors and allows reducing the uncertainty in the measurement, especially at low copy number, as observed with qPCR calibration curves generated by serial dilutions of the target. However, validated qPCR methods are not always simply transferable to the dPCR technology. Indeed, some optimization has to be carried out regarding, for instance, the design and the concentrations of primers and probes. In addition, given that maximum two different targets could be identified in one well, the low throughput power of the dPCR technology highlights its applicability more suitable at the identification/quantification level than at the screening step $[48,71,75,142]$.

2.4. Loop-Mediated Isothermal Amplification. Due to its rapidity, specificity, sensitivity, and simplicity, the loopmediated isothermal amplification (LAMP) method has been proposed to detect GMO (Figure 1). To this end, four primers specific to six distinct regions of the target are required, allowing, under isothermal condition, initiating the reaction and increasing the amplification speed by the formation of a loop structure. The amplification can be then directly visualized in the tube thanks to fluorescent dyes. Several LAMP markers were thus developed for this approach to target transgenic elements (Table 8) [76-91, 143].

The LAMP strategy presents the advantage to tolerate several PCR inhibitors such as acidic polysaccharides [84]. Its implementation does also not require any sophisticate devices. Indeed, the amplification could be carried out using a water bath or heating block [90]. Some of the developed LAMP methods have besides been successfully tested in 
TABLE 7: Representative examples illustrating digital PCR strategies targeting GMO.

\begin{tabular}{|c|c|c|c|c|}
\hline Multiplexing & Techniques & Methods & Targets & References \\
\hline \multirow[b]{3}{*}{ Simplex } & \multirow[b]{3}{*}{ cdPCR } & Taxon-specific & HMG, LEC, GLU, and CRU & \multirow[b]{3}{*}[69]{} \\
\hline & & Element-specific & $\begin{array}{l}\text { p35S, tNOS, CrylAb, CrylF, bar, CP4-EPSPS, Cry3Bb, nptII, CrylA.105, } \\
\text { and Cry2Bb }\end{array}$ & \\
\hline & & Event-specific & $\begin{array}{l}\text { MON531, MON88913, MON1445, MON15985, LLCOTTON25, GHB614, } \\
\text { 3272, DAS-59122-7, Bt176, Bt11, GA21, MIR162, MIR604, MON810, } \\
\text { MON863, MON88017, MON89034, NK603, T25, TC1507, Ms1, } \\
\text { Topas19/2, OXY_235, Ms8, Rf3, GT73, T45, GTS40-3-2, A2704-12, } \\
\text { MON89788, MON87701, DP-356043-5, A5547-127, BPS-CV-127, } \\
\text { DP-305423-1, and TT51-1 }\end{array}$ & \\
\hline \multirow{3}{*}{ Simplex } & \multirow{3}{*}{ cdPCR } & Taxon-specific & $\mathrm{ADH}, \mathrm{CRU}, \mathrm{PLD}, \mathrm{LEC}$, and adhC & \multirow[b]{3}{*}[70]{} \\
\hline & & Element-specific & p35S, pFMV, tNOS, CrylAb, bar, pat, and nptII & \\
\hline & & Event-specific & $\begin{array}{l}\text { 3272, Bt11, GA21, MON89034, MON810, MIR604, MON88017, TC1507, } \\
\text { Bt176, GTS40-3-1, DP-305423-1, DP-356043-5, H7-1, and GT73 }\end{array}$ & \\
\hline \multirow{2}{*}{ Simplex } & \multirow{2}{*}{ ddPCR } & Taxon-specific & HMG & \multirow[b]{2}{*}[71]{} \\
\hline & & Event-specific & MON810 & \\
\hline \multirow{2}{*}{ Duplex } & \multirow{2}{*}{ cdPCR } & Taxon-specific & $\mathrm{HMG}$ & \multirow{2}{*}[72-74]{} \\
\hline & & Event-specific & MON810 & \\
\hline \multirow[b]{2}{*}{ Duplex } & \multirow[b]{2}{*}{ ddPCR } & Taxon-specific & LEC & \multirow[b]{2}{*}[48,75]{} \\
\hline & & Event-specific & $\begin{array}{l}\text { DP-356043-5, DP-305423-1, MON89788, GTS40-3-2, A5547-127, } \\
\text { BPS-CV-127, A2704-12, MON87701, MON87708, MON87705, FG72, } \\
\text { and MON87769 }\end{array}$ & \\
\hline \multirow{2}{*}{ Duplex } & \multirow{2}{*}{ ddPCR } & Taxon-specific & PLD & \multirow[b]{2}{*}[75]{} \\
\hline & & Event-specific & LLRICE62 and KMD1 & \\
\hline \multirow[b]{2}{*}{ Duplex } & \multirow[b]{2}{*}{ ddPCR } & Taxon-specific & HMG & \multirow[b]{2}{*}[75]{} \\
\hline & & Event-specific & $\begin{array}{l}\text { Bt176, Bt11, MON810, NK603, Starllink, MON863, GA21, DAS-59122-7, } \\
\text { MIR162, MIR604, 3272, T25, TC1507, MON88017, MON89034, and } \\
\text { DAS-40278-9 }\end{array}$ & \\
\hline \multirow{2}{*}{ Duplex } & \multirow{2}{*}{ ddPCR } & Taxon-specific & HMG & \multirow[b]{2}{*}[71]{} \\
\hline & & Event-specific & MON810 & \\
\hline
\end{tabular}

$\mathrm{ADH}$ (alcohol dehydrogenase I gene from maize); adhC (alcohol dehydrogenase $\mathrm{C}$ gene from cotton); bar (phosphinothricin- $\mathrm{N}$-acetyltransferases gene from Streptomyces hygroscopicus); CP4-EPSPS (5-enolpyruvylshikimate-3-phosphate synthase gene from Agrobacterium tumefaciens strain); CRU (cruciferin gene from colza); Cry (gene encoding the Bacillus thuringiensis $\delta$-endotoxin); GLU (glutamine synthetase gene from sugar beet); HMG (major high-mobility group protein gene from maize); LEC (lectin gene from soybean); nptII (neomycin phosphotransferase II gene); p35S (promoter of the $35 \mathrm{~S}$ cauliflower mosaic virus); pat (phosphinothricin-N-acetyltransferases gene from Streptomyces viridochromogenes); pFMV (promoter of the figwort mosaic virus); phy (phytase gene from maize); PLD (phospholipase D gene from rice); pNOS (promoter of the nopaline synthase gene); tNOS (terminator of the nopaline synthase gene).

the fields [84]. Concerning the drawbacks, the design of four primers per target, which guarantee the high specificity and sensitivity of the LAMP, could be difficult. In addition, the identification of several GM targets using a multiplex assay is not applicable [28].

2.5. DNA Walking. In using PCR-based methods that required prior knowledge, the observed results are mostly generated in targeting elements derived from natural organisms. Therefore, they constitute merely an indirect proof of the presence of GMO in the tested food/feed matrices. In addition, when the observed signals do not correspond to known GMO, the presence of unknown GMO, containing at least one known element, could be only suspected. The only way to indubitably confirm the presence of GMO is provided by the characterization of sequences from the junctions between the transgenic cassette and the plant genome as well as the unnatural associations of transgenic elements.
To get this crucial information, several strategies of DNA walking, also called genome walking, have been reported (Figure 1 and Table 9). More precisely, this molecular technique allows identifying unknown nucleotide sequences adjacent to already known DNA regions in any given genome using specific primers to the known sequence combined to primers dictated by the DNA walking method used. Then, the final PCR products are usually sequenced by Sanger technology to be eventually analyzed with available databases (e.g., NCBI and JRC GMO-Amplicons). Classically, three main categories of DNA walking are established, based on the characteristics of their first step [144].

First, the restriction-based methods involve a digestion of the genomic DNA using appropriate restriction enzymes targeting sites close to sequences of interest, such as the junction between the known and unknown sequences. The obtained restriction fragments are then either self-circularized or ligated to DNA cassettes, named, respectively, inverted-PCR 
TABLE 8: Representative examples illustrating simplex LAMP strategies targeting GMO.

\begin{tabular}{|c|c|c|}
\hline Methods & Targets & References \\
\hline \multirow{4}{*}{ Taxon-specific } & $\mathrm{ADH}$ & {$[76]$} \\
\hline & LEC & {$[77,78]$} \\
\hline & PLD & [79] \\
\hline & IVR & {$[80]$} \\
\hline \multirow{15}{*}{ Element-specific } & $\mathrm{p} 35 \mathrm{~S}$ & {$[76,81-86]$} \\
\hline & pFMV & {$[83,86]$} \\
\hline & aadA & {$[83]$} \\
\hline & uidA & {$[83]$} \\
\hline & nptII & {$[83,86]$} \\
\hline & CrylAb & [87] \\
\hline & tNOS & {$[76,78,82,84,86]$} \\
\hline & pNOS & {$[82]$} \\
\hline & bar & {$[84,86]$} \\
\hline & pat & {$[86]$} \\
\hline & CrylAc & {$[86]$} \\
\hline & CP4-EPSPS & {$[86]$} \\
\hline & Cry2A & {$[88]$} \\
\hline & Cry3A & [88] \\
\hline & phy & [89] \\
\hline Construct-specific & p35S/EPSPS & {$[82]$} \\
\hline \multirow{15}{*}{ Event-specific } & Ms8 & {$[82]$} \\
\hline & Rf3 & {$[82]$} \\
\hline & MON89788 & {$[77,78,84]$} \\
\hline & GTS 40-3-2 & {$[77,78,84]$} \\
\hline & DAS-59122-7 & {$[80,84]$} \\
\hline & MON863 & {$[80,84]$} \\
\hline & TC1507 & {$[80,84]$} \\
\hline & $\mathrm{T} 25$ & {$[80,90]$} \\
\hline & Bt1l & [80] \\
\hline & Bt176 & {$[80]$} \\
\hline & MON810 & {$[80]$} \\
\hline & B73-6-1 & {$[91]$} \\
\hline & KMD1 & [79] \\
\hline & Kefeng-6 & [79] \\
\hline & TT51-1 & [79] \\
\hline
\end{tabular}

aadA (aminoglycoside $3^{\prime}$-adenylyltransferase); ACC (acetyl-CoAcarboxylase gene from colza); ADH (alcohol dehydrogenase I gene from maize); bar (phosphinothricin-N-acetyltransferases gene from Streptomyces hygroscopicus); CP4-EPSPS (5-enolpyruvylshikimate-3-phosphate synthase gene from Agrobacterium tumefaciens strain); Cry (gene encoding the Bacillus thuringiensis $\delta$-endotoxin); IVR (invertase gene from maize); LEC (lectin gene from soybean); nptII (neomycin phosphotransferase II gene); p35S (promoter of the $35 \mathrm{~S}$ cauliflower mosaic virus); pat (phosphinothricin$\mathrm{N}$-acetyltransferases gene from Streptomyces viridochromogenes); $\mathrm{pFMV}$ (promoter of the figwort mosaic virus); phy (phytase gene from maize); PLD (phospholipase D gene from rice); pNOS (promoter of the nopaline synthase gene); tNOS (terminator of the nopaline synthase gene); uidA ( $\beta$-glucuronidase).

and cassette PCR methods ([144] and references therein). By this way, several sequences of transgene flanking regions and unnatural associations from transgenic Arabidopsis thaliana, tobacco, shallot, potato, barley, grapefruit, tomato, banana, cotton (MON1445), colza (including GT73), soybean (GTS40-3-2 and MON89788), wheat (B73-6-1, B72-8-11, and B72-8-11b), rice (including TC-19, Bt Shanyou 63 (TT511), KeFeng-6, and KeFeng-8), and maize (CHB-351, Bt176, GA21, Bt1l, MON88017, MON863 × NK603, MON863 × NK603 × MON810, T25, MON810, NK603, MON863, T25, DAS-59122-7, LY038, and 3272) were characterized (Table 9) [92-108, 145-168].

Second, the extension-based methods are defined by the extension of a sequence-specific primer. The resulting single-stranded DNA is subsequently ligated to either a DNA cassette or $3^{\prime}$-tailing ([144] and references therein). This strategy was successfully applied on GM maize (MON810), rice (LLRICE62), soybean (A2704-12), rapeseed (T45), and cotton (LLCOTTON25) events in order to characterize their transgenic cassettes and transgene flanking regions (Table 9) $[109,110]$.

Third, the primer-based methods combine combinatorial (random and/or degenerate) primers to target-specific primers according to various PCR strategies ([144] and references therein). The transgenic Arabidopsis thaliana, tobacco, potato, barley, apple, banana, soybean, wheat (B73-6-1), rice (including KeFeng-6 and KMD1), and maize (including MON863 and MIR162) were thereby identified via the sequences of their transgene flanking regions and unnatural associations of elements (Table 9) [111-116, 152, 154, 157, 169174].

However, the implementation of most of these DNA walking methods by the enforcement laboratories presents some difficulties such as an insufficient specificity, sensitivity, or yield. Moreover, some of them use laborious, complex, and lengthy techniques (e.g., fingerprinting by capillary electrophoresis and genomic DNA library via (unpredictable) restriction enzyme). Therefore, a DNA walking approach, corresponding better to the need of enforcement laboratories, has been developed and validated on unprocessed and processed food matrices containing minute amounts of GM targets. As this DNA walking approach implies two seminested PCR rounds, the yield and the specificity of GM targets are increased, especially crucial in case of a low level presence of GMO. This approach, belonging to the PCR-based method category, has also the advantage to be fully integrated into the GMO routine analysis as the similar primers are used for the qPCR screening (detection of potential GMO presence) and the DNA walking (GMO identification). So, this simple and rapid approach could easily be applied by the enforcement laboratories, without any significant additional cost and equipment, to confirm signals previously obtained in qPCR (Table 9) [33, 117, 118].

Since DNA walking requires less prior knowledge about the sequence of interest than conventional PCR-based methods previously described, GMO with entirely or partially known sequences could be characterized. Therefore, in targeting key elements, such as p35S and tNOS that are highly frequent in GM crops, a broad range of GMO could be characterized [96, 106, 110, 111, 113, 118, 156]. In order to especially identify unauthorized GMO in European Union, a 
TABLE 9: Representative examples illustrating DNA walking strategies targeting GMO.

\begin{tabular}{|c|c|c|c|}
\hline DNA walking approaches & Characterized regions & Targets & References \\
\hline \multicolumn{4}{|c|}{ Restriction-based methods } \\
\hline Inverse PCR & Transgene flanking regions & Bt11 & {$[92,93]$} \\
\hline \multirow{25}{*}{ Cassette PCR } & Transgene flanking regions & GTS40-3-2 & [94] \\
\hline & Transgene flanking regions & GT73 & [95] \\
\hline & Transgene flanking regions & MON1445 & [96] \\
\hline & Transgene flanking regions & TC-19 & {$[97]$} \\
\hline & Transgene flanking regions & TT51-1 & {$[98]$} \\
\hline & Transgene flanking regions & KeFeng-6 & {$[99]$} \\
\hline & Transgene flanking regions & KeFeng-8 & {$[100]$} \\
\hline & Transgene flanking regions & B73-6-1 & {$[101]$} \\
\hline & Transgene flanking regions & B72-8-11 & {$[102]$} \\
\hline & Transgene flanking regions & $\mathrm{B} 72-8-11 \mathrm{~b}$ & {$[103]$} \\
\hline & Transgene flanking regions & LY038 & {$[104]$} \\
\hline & Transgene flanking regions & MON89788 & {$[104]$} \\
\hline & Transgene flanking regions & 3272 & {$[104]$} \\
\hline & Transgene flanking regions and unnatural element associations & CHB-351 & {$[105,106]$} \\
\hline & Transgene flanking regions and unnatural element associations & Bt176 & {$[95,106]$} \\
\hline & Transgene flanking regions and unnatural element associations & GA21 & {$[95,106]$} \\
\hline & Transgene flanking regions and unnatural element associations & Bt11 & {$[95,106]$} \\
\hline & Transgene flanking regions and unnatural element associations & $\mathrm{T} 25$ & {$[106,107]$} \\
\hline & Transgene flanking regions and unnatural element associations & MON810 & {$[106,108]$} \\
\hline & Transgene flanking regions and unnatural element associations & DAS-59122-7 & {$[104,106]$} \\
\hline & Unnatural element associations & MON88017 & [106] \\
\hline & Unnatural element associations & MON863 × NK603 & [106] \\
\hline & $\begin{array}{l}\text { Unnatural element associations } \\
\text { Unnatural element associations }\end{array}$ & $\begin{array}{c}\text { MON863 } \times \text { NK603 } \times \\
\text { MON810 }\end{array}$ & [106] \\
\hline & Unnatural element associations & NK603 & {$[106]$} \\
\hline & Unnatural element associations & MON863 & {$[106]$} \\
\hline \multicolumn{4}{|c|}{ Extension-based methods } \\
\hline \multirow{5}{*}{ LT-RADE } & Transgene flanking regions and unnatural element associations & MON810 & {$[109,110]$} \\
\hline & Transgene flanking regions and unnatural element associations & LLRICE62 & {$[109,110]$} \\
\hline & Transgene flanking regions and unnatural element associations & $\mathrm{T} 45$ & {$[110]$} \\
\hline & Transgene flanking regions and unnatural element associations & A2704-12 & [110] \\
\hline & Transgene flanking regions and unnatural element associations & LLCOTTON25 & [110] \\
\hline \multicolumn{4}{|c|}{ PCR-based methods } \\
\hline \multirow{3}{*}{ TAIL-PCR } & Transgene flanking regions & MON863 & {$[111,112]$} \\
\hline & Transgene flanking regions & KeFeng-6 & {$[113]$} \\
\hline & Transgene flanking regions & B73-6-1 & {$[114]$} \\
\hline \multirow{2}{*}{ SiteFinding PCR } & Transgene flanking regions & KMD1 & {$[115]$} \\
\hline & Unnatural element associations & MIR162 & [116] \\
\hline \multirow{2}{*}{$\begin{array}{l}\text { APAgene GOLD Genome } \\
\text { Walking Kit }\end{array}$} & Transgene flanking regions and unnatural element associations & Bt rice & {$[33,117,118]$} \\
\hline & Transgene flanking regions and unnatural element associations & MON863 & {$[118]$} \\
\hline
\end{tabular}

DNA walking approach using primers specific to the element $\mathrm{t} 35 \mathrm{~S}$ from the pCAMBIA vector, found in approximately $30 \%$ of transgenic plants, was developed [33, 117]. However, the DNA walking strategy is not suitable to GMO containing only unknown elements.
2.6. Next Generation Sequencing Technologies. Despite their higher throughput compared to qPCR, the multiplex strategies described above require the prior knowledge of at least a part of the GMO sequences. Once the information about these sequences is collected, the development of methods, 
TABLE 10: Representative examples illustrating NGS strategies targeting GMO.

\begin{tabular}{|c|c|c|c|c|}
\hline NGS strategies & NGS platforms & Targets & Target sizes & References \\
\hline \multirow{10}{*}{ Targeted sequencing } & HiSeq (Illumina) & vip3Aa2 from MIR162 & $150 \mathrm{bp}$ to $2 \mathrm{Kbp}$ & [116] \\
\hline & PacBio RS (Pacific Biosciences) & vip3Aa2 from MIR162 & $150 \mathrm{bp}$ to $2 \mathrm{Kbp}$ & [116] \\
\hline & 454 system (Roche Applied Science) & ssIIb & $157 \mathrm{bp}$ & [119] \\
\hline & 454 system (Roche Applied Science) & Bt1l gene & $324 \mathrm{bp}$ & [119] \\
\hline & 454 system (Roche Applied Science) & Bt176 gene & $206 \mathrm{bp}$ & [119] \\
\hline & 454 system (Roche Applied Science) & LEC & 118 bp & [119] \\
\hline & 454 system (Roche Applied Science) & $\mathrm{p} 35 \mathrm{~S} / \mathrm{CTP} 4$ & $171 b p$ & [119] \\
\hline & 454 system (Roche Applied Science) & CP4-EPSPS & $498 \mathrm{bp}$ & [119] \\
\hline & 454 system (Roche Applied Science) & $\mathrm{p} 35 \mathrm{~S}$ & $195 \mathrm{bp}$ & [119] \\
\hline & 454 system (Roche Applied Science) & $\mathrm{tNOS}$ & $180 \mathrm{bp}$ & [119] \\
\hline \multirow{7}{*}{ Whole genome sequencing } & HiSeq (Illumina) & MON17903 soybean & $1115 \mathrm{Mbp}$ & {$[120]$} \\
\hline & HiSeq (Illumina) & MON87704 soybean & $1115 \mathrm{Mbp}$ & {$[120]$} \\
\hline & HiSeq (Illumina) & FP967 flax & $373 \mathrm{Mbp}$ & [121] \\
\hline & HiSeq (Illumina) & LLRICE62 rice & $385 \mathrm{Mbp}$ & {$[122]$} \\
\hline & HiSeq (Illumina) & TT51-1 rice & $385 \mathrm{Mbp}$ & {$[123]$} \\
\hline & HiSeq (Illumina) & T1c-19 rice & $385 \mathrm{Mbp}$ & {$[123]$} \\
\hline & HiSeq (Illumina) & Bt rice & $385 \mathrm{Mbp}$ & {$[124]$} \\
\hline
\end{tabular}

CP4-EPSPS (5-enolpyruvylshikimate-3-phosphate synthase gene from Agrobacterium tumefaciens strain); CTP4 (chloroplast transit peptide 4 from the Arabidopsis thaliana epsps gene); LEC (lectin gene from soybean); p35S (promoter of the $35 \mathrm{~S}$ cauliflower mosaic virus); ssIIb (starch synthase IIb gene from maize); tNOS (terminator of the nopaline synthase gene); VIP3A (vegetative insecticidal protein $3 \mathrm{~A}$ ).

each one targeting indivdually one sequence of interest, is carried out on a case-by-case basis. Then, the optimisation of unbiased multiplex assays presenting equal analytical performance compared to simplex assays remains laborious and intricate. Furthermore, the issues related to the detection of GMO containing no known sequences are still unsolved. Recently, NGS, allowing a massive parallel DNA sequencing, has been suggested to tackle these challenges. The NGS technology outperforms plainly the classical Sanger sequencing in terms of rapidity and throughput. Indeed, the powerful high throughput of NGS offers the possibility to sequence simultaneously many different samples, discriminable in using a wide range of barcodes [116, 124, 175]. Two main strategies, sequencing samples that are earlier enriched with sequences of interest (targeted sequencing approach) or not (whole genome sequencing (WGS) approach), exist (Figure 1 and Table 10).

2.6.1. Targeted Sequencing. The targeted sequencing strategy is especially beneficial to target regions of interest from large and complex genomes, observed in most of plants. Even if a minimum of prior knowledge on sequences is needed to target the sequences of interest, it presents the advantage to use exclusively all the energy, in terms of time and cost, on the regions of interest. With this strategy, two substrategies could be used, involving the sequencing of either DNA library of PCR products (amplicon sequencing) or selected DNA fragments from a whole genome library (target enrichment sequencing) (Figure 1).

On the one hand, as the amplicon sequencing allows characterizing DNA fragments of interest previously enriched by PCR, this sequencing approach depends thus clearly on the PCR strategy adopted upstream as well as its inherent properties and performance. In order to detect GMO, Song et al., 2014 generated amplicons by PCR, using primers targeting maize endogen gene, Bt11 gene, Bt176 gene, soybean endogen gene, 35S/CTP4 construct, CP4-EPSPS element, p35S promoter, and tNOS terminator, from samples containing a low amount of GM targets (1\% of Bt11 maize, 2\% of Bt176 maize, $2 \%$ of GTS40-3-2 soybean, $1 \%$ of GTS40-3-2 soybean, $0.1 \%$ of GTS40-3-2 soybean, or $0.01 \%$ of GTS40-3-2 soybean). Then, each kind of amplicons was individually sequenced using a variant of the 454 system called pyrosequencing on portable photodiode-based bioluminescence sequencer that is more sensitive, compact, and cost-efficient compared to the original 454 technology (Roche) (Table 10) [119, 176]. This approach is relatively similar to the PCR screening with the additional value to provide, instead of positive or negative signals, the sequence of the amplified fragments, which is more reliable to prove the presence of GMO. Conversely to this approach, Liang et al., 2014 suggest an amplicon sequencing strategy allowing analyzing GMO for which the sequence information is only partially known. To this end, a DNA walking method (SiteFinding PCR), targeting the vip3Aa20 sequence, was coupled to NGS technologies, using the Illumina or Pacific Biosciences platforms, to characterize the sequences of the MIR162 maize event (Table 10). Even if the results were similar using the two different NGS platforms, the PacBio system shows the advantage to sequence DNA fragments with a size reaching up to $40 \mathrm{Kbp}$ and to deal with DNA fragments presenting different sizes. Therefore, the PacBio system, in contrast to the Illumina technology, allows in many cases avoiding a de novo assembly step as the shearing of genomic DNA is not always required. Moreover, the use of NGS instead of the Sanger technology allows considerably 
increasing the throughput of DNA walking approaches. Indeed, in order to guarantee the entire representativeness of GMO present in a tested sample, all observed amplicons should be analyzed. However, the purification of the potential numerous amplicons excised from the electrophoresis gel and the subsequent Sanger sequencing could be cumbersome, especially in case of food/feed matrices containing several GMO sharing common targeted elements [116, 118, 177].

On the other hand, the target enrichment sequencing approach involves the selection of sequences of interest from the whole genome DNA library. To capture them, appropriate hybridization methods could be used relying on magnetic beads or microarrays associated with specific probes. The efficiency of the hybridization step is thus crucial for this sequencing strategy. The DNA fragments containing entirely or partially the known regions could be then sequenced. However, even if this strategy has been applied to different plants, no study has to date been reported to our knowledge to detect GMO [178-181].

The analysis of preenriched DNA fragments of interest with NGS technology allows proving the presence of GMO in characterizing sequences entirely or partially known beforehand. However, given its relative high cost, expected to decrease over the time, and the prerequisite bioinformatics expertise, the targeted NGS strategy could not reasonably be currently applied routinely to all food/feed matrices by the enforcement laboratories [116, 124, 175].

2.6.2. Whole Genome Sequencing. The WGS strategy allows in principle characterizing a sample without any prior knowledge (Figure 1). With this sequencing strategy, the entire DNA library, consisting of sheared genomic DNA ligated to adaptors, is sequenced. The generated reads are then treated with bioinformatics tools based on prior knowledge of tested GMO.

First, when no information about the transgenic cassette is available, the insert and its transgene flanking regions are identified by the analysis of all inferred contigs derived from reads that partially matched or unmatched with the endogenous plant-species reference genome [123]. This WGS strategy was applied on the LLRICE62 event by using the available reference genome of Oryza sativa ssp. Japonica. As the results corresponded to the information from the developer dossier, the characterization of GMO with an unknown insert using NGS was thus demonstrated (Table 10) [122]. Similarly, the T-DNA regions from the GM flax FP967 event and the transgenic rice TT51-1 and T1c-19 events were also characterized (Table 10) [121, 123]. The success of this strategy is thus linked to the availability of good reference genomes for specific varieties and organisms. In case of no reference genome available, a strategy of de novo assembly, comparing all generated reads to find overlaps, has to be applied. However, this remains quite cumbersome with the large and complex plant genomes notably in terms of ploidy, repeated regions, and heterozygosity and with mixtures of different GMO $[120,182]$. To facilitate even so the de novo assembly, the strength of different NGS platforms can be associated. For instance, short reads from Illumina technology can be aligned to long reads generated by the PacBio technology, constituting a substitute of reference genome [183].

Second, with the condition that the sequence of at least one transgenic element is known, the insert is de novo assembled with reads that are matched and unmatched with a DNA transgene sequence library containing frequently used transgenic elements. This approach was tested on the transgenic rice TT51-1 and T1c-19 events (Table 10) [123].

Third, if the sequence of the insert is known, two kinds of bioinformatics analysis have been reported. On the one hand, the reads, corresponding not entirely to the reference genome, are mapped to the transgenic cassette sequence in order to determine the number of inserts and their transgene flanking regions. By this way, the GM rice TT51-1 and T1c19 events and the GM soybean MON17903 and MON87704 events were characterized (Table 10) $[120,123]$. On the other hand, Willems et al., 2016 have developed an analytical workflow, including three different approaches. The detection approach, consisting of comparing the reads to the reference sequence of the insert, allows detecting the presence of GMO in a given sample. To confirm the integration of the transgenic cassette and provide a rough localization of its flanking regions, the matched reads are then compared to the reference sequence of the host genome in the proof approach. By the simultaneous aligning of these selected reads to the host genome and the transgenic cassette, the identification approach allows determining precisely the localization of the transgenic cassette and the sequence of its flanking regions. This WGS strategy was initially assessed on pure transgenic $\mathrm{GM}$ rice (100\% $\mathrm{Bt}$ rice). Conversely to all the other WGS strategies described above, food/feed matrices more likely to be encountered in GMO routine analysis, such as a GM/nonGM rice mixture (10\% Bt rice) and a processed $\mathrm{GM}$ rice (100\% Bt noodles), have also been tested (Table 10) [124]. In this study, a statistical framework, predicting the probability to detect a sequence derived from a transgenic cassette and validated with experimental data originated from WGS, was also developed to estimate in silico the number of reads, derived from Illumina HiSeq device, required to characterize frequently encountered GMO. It was shown that samples composed of GMO at 100\%, except for GM wheat owning a huge genome, could be wisely characterized at a standard price range. A contrario, the detection, and identification of GMO present at trace level are not reasonably achievable by WGS [124]. Therefore, at the present time, only the previously described targeted sequencing approach can be applied on GM mixture containing GMO at trace level within reason.

The NGS technology is thus a promising alternative in the GMO detection field which offers the possibility to prove straightforward the presence of GMO in food/feed matrix via the characterization of their sequences. Moreover, the sequences obtained from unknown GMO will allow designing new PCR markers. Nevertheless, the implementation of NGS in GMO routine analysis by the enforcement laboratories is still difficult due to its relatively high cost as well as the requirement of adequate computer infrastructures and qualified analysts in bioinformatics for dealing with the generated data $[116,124,175]$. 


\section{Conclusion}

In GMO routine analysis, $\mathrm{qPCR}$ remains the method of choice for the enforcement laboratories. However, as some technical hurdles could be encountered with this technology, alternative GMO detection methods have been developed to raise some of these challenges. In order to exploit at best the performance of all the above described strategies, their applicability could be considered according to the adopted strategy of GMO detection as well as the available information about the sequences of tested GMO (Figure 1). In case of fully characterized GMO, the methods based on conventional PCR are absolutely appropriate to rapidly detect individually GM targets low-prized (LAMP), to simultaneously detect several GM targets (CGE, microarray, and Luminex) or to precisely quantify the amount of GM targets without impact of inhibitors (dPCR). However, when tested matrices contain GMO for which only a part of their sequences is known, these strategies could generate unexplained signals for which the observed positive signals could not be related to known GM events. In targeting key DNA sequences, such as the elements p35S and tNOS that are frequently found in GM plants, the use of DNA walking or targeted sequencing by enrichment strategies allows indubitably confirming the presence of GMO via the sequences of transgenes flanking regions and unnatural associations of genetic elements. If no information is available, at this moment, only the WGS is conceivable to characterize this category of GMO.

\section{Conflict of Interests}

The authors declare that they have no competing interests.

\section{Acknowledgment}

The research that yielded these results was funded by the Belgian Federal Public Service of Health, Food Chain Safety and Environment through the contact UGMMONITOR (convention RF 11/6242).

\section{References}

[1] C. James, "Global status of commercialized biotech/GM crops: 2014," ISAAA Brief 49, 2014.

[2] Cartagena Protocol on Biosafety, http://bch.cbd.int/protocol/.

[3] S. Kamle and S. Ali, "Genetically modified crops: detection strategies and biosafety issues," Gene, vol. 522, no. 2, pp. 123132, 2013.

[4] G. J. Rogan, Y. A. Dudin, T. C. Lee et al., "Immunodiagnostic methods for detection of 5-enolpyruvylshikimate-3-phosphate synthase in Roundup Ready soybeans," Food Control, vol. 10, no. 6, pp. 407-414, 1999.

[5] M. J. McKenzie, V. Mett, and P. E. Jameson, "Modified ELISA for the detection of neomycin phosphotransferase ii in transformed plant species," Plant Cell Reports, vol. 19, no. 3, pp. 286-289, 2000.

[6] M. Lipp, E. Anklam, J. W. Stave et al., "Validation of an immunoassay for detection and quantitation of a genetically modified soybean in food and food fractions using reference materials: interlaboratory study," Journal of AOAC International, vol. 83, no. 4, pp. 919-927, 2000.

[7] C. R. Lipton, J. X. Dautlick, G. D. Grothaus et al., "Guidelines for the validation and use of immunoassays for determination of introduced proteins in biotechnology enhanced crops and derived food ingredients," Food and Agricultural Immunology, vol. 12, no. 2, pp. 153-164, 2000.

[8] J. Fagan, B. Schoel, A. Haegert, J. Moore, and J. Beeby, "Performance assessment under field conditions of a rapid immunological test for transgenic soybeans," International Journal of Food Science and Technology, vol. 36, no. 4, pp. 357-367, 2001.

[9] E. Anklam, F. Gadani, P. Heinze, H. Pijnenburg, and G. Van Den Eede, "Analytical methods for detection and determination of genetically modified organisms in agricultural crops and plant-derived food products," European Food Research and Technology, vol. 214, no. 1, pp. 3-26, 2002.

[10] J. W. Stave, "Protein immunoassay methods for detection of biotech crops: applications, limitations, and practical considerations," Journal of AOAC International, vol. 85, no. 3, pp. 780-786, 2002.

[11] W. T. Xu, K. L. Huang, H. Zhao, and Y. B. Luo, "Application of immunoaffinity column as cleanup tool for an enzyme linked immunosorbent assay of phosphinothricin- $N$-acetyltransferase detection in genetically modified maize and rape," Journal of Agricultural and Food Chemistry, vol. 53, no. 11, pp. 4315-4321, 2005.

[12] M. Ermolli, A. Fantozzi, M. Marini et al., "Food safety: screening tests used to detect and quantify GMO proteins," Accreditation and Quality Assurance, vol. 11, no. 1-2, pp. 55-57, 2006.

[13] K. R. Emslie, L. Whaites, K. R. Griffiths, and E. J. Murby, "Sampling plan and test protocol for the semiquantitative detection of genetically modified canola (Brassica napus) seed in bulk canola seed," Journal of Agricultural and Food Chemistry, vol. 55, no. 11, pp. 4414-4421, 2007.

[14] G. Shan, S. K. Embrey, and B. W. Schafer, "A highly specific enzyme-linked immunosorbent assay for the detection of CrylAc insecticidal crystal protein in transgenic widestrike cotton," Journal of Agricultural and Food Chemistry, vol. 55, no. 15, pp. 5974-5979, 2007.

[15] C. Giovannoli, L. Anfossi, C. Baggiani, and G. Giraudi, "Binding properties of a monoclonal antibody against the CrylAb from Bacillus thuringensis for the development of a capillary electrophoresis competitive immunoassay," Analytical and Bioanalytical Chemistry, vol. 392, no. 3, pp. 385-393, 2008.

[16] D. S. Smith, P. W. Maxwell, and S. H. De Boer, "Evaluation of neomycin phosphotransferase II and Cry3A as targets for the serological detection of transgenic potato tubers," American Journal of Potato Research, vol. 85, no. 1, pp. 60-68, 2008.

[17] W. Xu, K. Huang, Z. Liang et al., "Application of stepwise ammonium sulfate precipitation as cleanup tool for an enzymelinked immunosorbent assay of glyphosate oxidoreductase in genetically modified rape of gt73," Journal of Food Biochemistry, vol. 33, no. 5, pp. 630-648, 2009.

[18] A. Székács, É. Lauber, E. Takács, and B. Darvas, "Detection of CrylAb toxin in the leaves of MON 810 transgenic maize," Analytical and Bioanalytical Chemistry, vol. 396, no. 6, pp. 22032211, 2010.

[19] S. Kamle, A. Ojha, and A. Kumar, "Development of an enzyme linked immunosorbant assay for the detection of Cry $2 \mathrm{Ab}$ protein in transgenic plants," GM Crops, vol. 2, no. 2, pp. 118125, 2011. 
[20] X. Zhu, L. Chen, P. Shen, J. Jia, D. Zhang, and L. Yang, "High sensitive detection of CrylAb protein using a quantum dotbased fluorescence-linked immunosorbent assay," Journal of Agricultural and Food Chemistry, vol. 59, no. 6, pp. 2184-2189, 2011.

[21] G. Y. Tan, T. G. Nan, W. Gao, Q. X. Li, J. J. Cui, and B. M. Wang, "Development of monoclonal antibody-based sensitive sandwich ELISA for the detection of antinutritional factor cowpea trypsin inhibitor," Food Analytical Methods, vol. 6, no. 2, pp. 614-620, 2013.

[22] H.-J. Jang, I.-H. Cho, H.-S. Kim, J.-W. Jeon, S.-Y. Hwang, and S.H. Paek, "Development of a chemiluminometric immunosensor array for on-site monitoring of genetically modified organisms," Sensors and Actuators, B: Chemical, vol. 155, no. 2, pp. 598-605, 2011.

[23] R. C. Allen, S. Rogelj, S. E. Cordova, and T. L. Kieft, "An immuno-PCR method for detecting Bacillus thuringiensis CrylAc toxin," Journal of Immunological Methods, vol. 308, no. 1-2, pp. 109-115, 2006.

[24] S. Santiago-Felipe, L. A. Tortajada-Genaro, R. Puchades, and A. Maquieira, "Recombinase polymerase and enzyme-linked immunosorbent assay as a DNA amplification-detection strategy for food analysis," Analytica Chimica Acta, vol. 811, pp. 81-87, 2014.

[25] V. García-Cañas, C. Simó, C. León, E. Ibáñez, and A. Cifuentes, "MS-based analytical methodologies to characterize genetically modified crops," Mass Spectrometry Reviews, vol. 30, no. 3, pp. 396-416, 2011.

[26] D. Morisset, D. Stebih, K. Cankar, J. Zel, and K. Gruden, "Alternative DNA amplification methods to PCR and their application in GMO detection: a review," European Food Research and Technology, vol. 227, no. 5, pp. 1287-1297, 2008.

[27] M. Mazzara, C. Paoletti, P. Corbisier et al., "Kernel lot distribution assessment (KeLDA): a comparative study of protein and DNA-based detection methods for GMO Testing," Food Analytical Methods, vol. 6, no. 1, pp. 210-220, 2013.

[28] A. Angers-Loustau, M. Petrillo, L. Bonfini et al., "JRC GMOMatrix: a web application to support genetically modified organisms detection strategies," BMC Bioinformatics, vol. 15, article 417, 2014.

[29] E. Navarro, G. Serrano-Heras, M. Castaño, and J. Solera, "Realtime PCR detection chemistry," Clinica Chimica Acta, vol. 439, pp. 231-250, 2015.

[30] S. Broeders, N. Papazova, M. Van den Bulcke, and N. Roosens, "Development of a molecular platform for GMO detection in food and feed on the basis of 'combinatory qPCR' technology," in Polymerase Chain Reaction, chapter 18, pp. 363-404, InTech, Rijeka, Croatia, 2012.

[31] E. Barbau-Piednoir, A. Lievens, G. Mbongolo-Mbella et al., "SYBR Green qPCR screening methods for the presence of '35S promoter' and 'NOS terminator' elements in food and feed products," European Food Research and Technology, vol. 230, no. 3, pp. 383-393, 2010.

[32] S. R. M. Broeders, S. C. J. de Keersmaecker, and N. H. C. Roosens, "How to deal with the upcoming challenges in GMO detection in food and feed," Journal of Biomedicine and Biotechnology, vol. 2012, Article ID 402418, 11 pages, 2012.

[33] M.-A. Fraiture, P. Herman, I. Taverniers, M. De Loose, D. Deforce, and N. H. Roosens, "An innovative and integrated approach based on DNA walking to identify unauthorised GMOs," Food Chemistry, vol. 147, pp. 60-69, 2014.
[34] S. Broeders, M. A. Fraiture, E. Vandermassen et al., "New trait-specific qualitative SYBR Green qPCR methods to expand the panel of GMO screening methods used in the CoSYPS," European Food Research and Technology, vol. 241, no. 2, pp. 275287,2015

[35] JCR GMOMETHODS, http://gmo-crl.jrc.ec.europa.eu/gmomethods/.

[36] M. Querci, M. Van den Bulcke, J. Žel, G. Van den Eede, and H. Broll, "New approaches in GMO detection," Analytical and Bioanalytical Chemistry, vol. 396, no. 6, pp. 1991-2002, 2010.

[37] E. G. M. Mbella, A. Lievens, E. Barbau-Piednoir et al., "SYBR Green qPCR methods for detection of endogenous reference genes in commodity crops: a step ahead in combinatory screening of genetically modified crops in food and feed products," European Food Research and Technology, vol. 232, no. 3, pp. 485496, 2011.

[38] H.-U. Waiblinger, B. Ernst, A. Anderson, and K. Pietsch, "Validation and collaborative study of a P35S and T-nos duplex real-time PCR screening method to detect genetically modified organisms in food products," European Food Research and Technology, vol. 226, no. 5, pp. 1221-1228, 2008.

[39] S. Broeders, E. Barbau-Piednoir, E. Vandermassen, F. Debode, M. Mazzara, and N. Roosens, "New SYBR green methods targeting promoter sequences used for screening of several GM events pending for authorisation in Europe," European Food Research and Technology, vol. 236, no. 3, pp. 537-547, 2013.

[40] E. Barbau-Piednoir, P. Stragier, N. Roosens et al., "Interlaboratory testing of GMO detection by combinatory SYBRGreen PCR screening (CoSYPS)," Food Analytical Methods, vol. 7, no. 8, pp. 1719-1728, 2014.

[41] I. Huber, A. Block, D. Sebah et al., "Development and validation of duplex, triplex, and pentaplex real-time PCR screening assays for the detection of genetically modified organisms in food and feed," Journal of Agricultural and Food Chemistry, vol. 61, no. 43, pp. 10293-10301, 2013.

[42] G. Cottenet, C. Blancpain, V. Sonnard, and P. F. Chuah, "Development and validation of a multiplex real-time PCR method to simultaneously detect 47 targets for the identification of genetically modified organisms," Analytical and Bioanalytical Chemistry, vol. 405, no. 21, pp. 6831-6844, 2013.

[43] M. Chaouachi, M. S. Zellama, N. Nabi, A. B. Hafsa, and K. Saïd, "Molecular identification of four genetically modified maize (Bt11, Bt176, Mon810 and T25) by duplex quantitative real-time PCR," Food Analytical Methods, vol. 7, no. 1, pp. 224-233, 2014.

[44] M. C. Samson, M. Gullí, and N. Marmiroli, "Multiplex real-time PCR assays for simultaneous detection of maize MON810 and GA21 in food samples," Food Control, vol. 30, no. 2, pp. 518-525, 2013.

[45] S.-B. Park, H.-Y. Kim, and J.-H. Kim, "Multiplex PCR system to track authorized and unauthorized genetically modified soybean events in food and feed," Food Control, vol. 54, pp. 4752, 2015.

[46] R. Köppel, A. Sendic, and H.-U. Waiblinger, "Two quantitative multiplex real-time PCR systems for the efficient GMO screening of food products," European Food Research and Technology, vol. 239, no. 4, pp. 653-659, 2014.

[47] H.-H. Dörries, I. Remus, A. Grönewald, C. Grönewald, and K. Berghof-Jäger, "Development of a qualitative, multiplex realtime PCR kit for screening of genetically modified organisms (GMOs)," Analytical and Bioanalytical Chemistry, vol. 396, no. 6, pp. 2043-2054, 2010. 
[48] R. Köppel, T. Bucher, A. Frei, and H. U. Waiblinger, "Droplet digital PCR versus multiplex real-time PCR method for the detection and quantification of DNA from the four transgenic soy traits MON87769, MON87708, MON87705 and FG72, and lectin," European Food Research and Technology, vol. 241, no. 4, pp. 521-527, 2015.

[49] C. Bahrdt, A. B. Krech, A. Wurz, and D. Wulff, "Validation of a newly developed hexaplex real-time PCR assay for screening for presence of GMOs in food, feed and seed," Analytical and Bioanalytical Chemistry, vol. 396, no. 6, pp. 2103-2112, 2010.

[50] A. Burrell, C. Foy, and M. Burns, "Applicability of three alternative instruments for food authenticity analysis: GMO identification," Biotechnology Research International, vol. 2011, Article ID 838232, 8 pages, 2011.

[51] S. Basak, N. Z. Ehtesham, B. Sesikeran, and S. Ghosh, "Detection and identification of transgenic elements by fluorescentPCR-based capillary gel electrophoresis in genetically modified cotton and soybean," Journal of AOAC International, vol. 97, no. 1, pp. 159-165, 2014.

[52] A. Nadal, A. Coll, J.-L. La Paz, T. Esteve, and M. Pla, "A new PCR-CGE (size and color) method for simultaneous detection of genetically modified maize events," Electrophoresis, vol. 27, no. 19, pp. 3879-3888, 2006.

[53] A. Nadal, T. Esteve, and M. Pla, "Multiplex polymerase chain reaction-capillary gel electrophoresis: a promising tool for GMO screening-assay for simultaneous detection of five genetically modified cotton events and species," Journal of AOAC International, vol. 92, no. 3, pp. 765-772, 2009.

[54] A. Holck, B. O. Pedersen, and E. Heir, "Detection of five novel GMO maize events by qualitative, multiplex PCR and fluorescence capillary gel electrophoresis," European Food Research and Technology, vol. 231, no. 3, pp. 475-483, 2010.

[55] A. L. Holck and B. O. Pedersen, "Simple, sensitive, accurate multiplex quantitative competitive PCR with capillary electrophoresis detection for the determination of genetically modified maize," European Food Research and Technology, vol. 233, no. 6, pp. 951-961, 2011.

[56] J. Guo, L. Yang, L. Chen et al., "MPIC: a high-throughput analytical method for multiple DNA targets," Analytical Chemistry, vol. 83, no. 5, pp. 1579-1586, 2011.

[57] B. R. Heide, S. M. Drømtorp, K. Rudi, E. Heir, and A. L. Holck, "Determination of eight genetically modified maize events by quantitative, multiplex PCR and fluorescence capillary gel electrophoresis," European Food Research and Technology, vol. 227, no. 4, pp. 1125-1137, 2008.

[58] B. R. Heide, E. Heir, and A. Holck, "Detection of eight GMO maize events by qualitative, multiplex PCR and fluorescence capillary gel electrophoresis," European Food Research and Technology, vol. 227, no. 2, pp. 527-535, 2008.

[59] S. Leimanis, M. Hernández, S. Fernández et al., "A microarraybased detection system for genetically modified (GM) food ingredients," Plant Molecular Biology, vol. 61, no. 1-2, pp. 123139, 2006.

[60] S. Leimanis, S. Hamels, F. Nazé et al., "Validation of the performance of a GMO multiplex screening assay based on microarray detection," European Food Research and Technology, vol. 227, no. 6, pp. 1621-1632, 2008.

[61] S. Hamels, T. Glouden, K. Gillard et al., "A PCR-microarray method for the screening of genetically modified organisms," European Food Research and Technology, vol. 228, no. 4, pp. 531$541,2009$.
[62] D. Morisset, D. Dobnik, S. Hamels, J. Žel, and K. Gruden, "NAIMA: target amplification strategy allowing quantitative on-chip detection of GMOs," Nucleic Acids Research, vol. 36, no. 18, article el18, 2008.

[63] K. Rudi, I. Rud, and A. Holck, "A novel multiplex quantitative DNA array based PCR (MQDA-PCR) for quantification of transgenic maize in food and feed," Nucleic Acids Research, vol. 31, no. 11, article e62, 2003.

[64] T. W. Prins, J. P. van Dijk, H. G. Beenen et al., "Optimised padlock probe ligation and microarray detection of multiple (non-authorised) GMOs in a single reaction," BMC Genomics, vol. 9, article 584, 2008.

[65] A. Fantozzi, M. Ermolli, M. Marini, B. Balla, M. Querci, and G. Van den Eede, "Innovative application of fluorescent microsphere based assay for multiple GMO detection," Food Analytical Methods, vol. 1, no. 1, pp. 10-17, 2008.

[66] X. Han, H. Wang, H. Chen et al., "Development and primary application of a fluorescent liquid bead array for the simultaneous identification of multiple genetically modified maize," Biosensors and Bioelectronics, vol. 49, pp. 360-366, 2013.

[67] S. H. Choi, Y. T. Oh, J. Y. Kwon, S. N. Lee, B. D. Han, and K. H. Ryu, "Development of detection system using multiplex PCR and liquid beadarray for stacked genetically modified rice event (LS28 $\times$ CrylAc)," Journal of the Korean Society for Applied Biological Chemistry, vol. 53, no. 5, pp. 639-646, 2010.

[68] S. H. Choi, "Hexaplex PCR assay and liquid bead array for detection of stacked genetically modified cotton event 281-24236×3006-210-23," Analytical and Bioanalytical Chemistry, vol. 401, no. 2, pp. 647-655, 2011.

[69] F. C. A. Brod, J. P. Van Dijk, M. M. Voorhuijzen et al., "A high-throughput method for GMO multi-detection using a microfluidic dynamic array," Analytical and Bioanalytical Chemistry, vol. 406, no. 5, pp. 1397-1410, 2014.

[70] X. Li, Y. Wu, J. Li et al., "Development and validation of a 48-target analytical method for high-throughput monitoring of genetically modified organisms," Scientific Reports, vol. 5, p. 7616, 2015.

[71] D. Morisset, D. Štebih, M. Milavec, K. Gruden, and J. Žel, "Quantitative analysis of food and feed samples with droplet digital PCR," PLoS ONE, vol. 8, no. 5, Article ID e62583, 2013.

[72] S. Bhat, J. Herrmann, P. Armishaw, P. Corbisier, and K. R. Emslie, "Single molecule detection in nanofluidic digital array enables accurate measurement of DNA copy number," Analytical and Bioanalytical Chemistry, vol. 394, no. 2, pp. 457-467, 2009.

[73] P. Corbisier, S. Bhat, L. Partis, V. R. D. Xie, and K. R. Emslie, "Absolute quantification of genetically modified MON810 maize (Zea mays L.) by digital polymerase chain reaction," Analytical and Bioanalytical Chemistry, vol. 396, no. 6, pp. 2143-2150, 2010.

[74] M. J. Burns, A. M. Burrell, and C. A. Foy, "The applicability of digital PCR for the assessment of detection limits in GMO analysis," European Food Research and Technology, vol. 231, no. 3, pp. 353-362, 2010.

[75] R. Köppel and T. Bucher, "Rapid establishment of droplet digital PCR for quantitative GMO analysis," European Food Research and Technology, vol. 241, no. 3, pp. 427-439, 2015.

[76] G. Kiddle, P. Hardinge, N. Buttigieg et al., "GMO detection using a bioluminescent real time reporter (BART) of loop mediated isothermal amplification (LAMP) suitable for field use," BMC Biotechnology, vol. 12, article 15, 2012.

[77] X. Guan, J. Guo, P. Shen, L. Yang, and D. Zhang, "Visual and rapid detection of two genetically modified soybean events 
using loop-mediated isothermal amplification method," Food Analytical Methods, vol. 3, no. 4, pp. 313-320, 2010.

[78] H. Di, L. Shi, H. Shen et al., "Rapid detection of genetically modified ingredients in soybean products by real-time loopmediated isothermal amplification," Journal of Food and Nutrition Research, vol. 2, no. 7, pp. 363-368, 2014.

[79] X. Chen, X. Wang, N. Jin et al., "Endpoint visual detection of three genetically modified rice events by loop-mediated isothermal amplification," International Journal of Molecular Sciences, vol. 13, no. 11, pp. 14421-14433, 2012.

[80] L. Chen, J. Guo, Q. Wang, G. Kai, and L. Yang, "Development of the visual loop-mediated isothermal amplification assays for seven genetically modified maize events and their application in practical samples analysis," Journal of Agricultural and Food Chemistry, vol. 59, no. 11, pp. 5914-5918, 2011.

[81] S. Fukuta, Y. Mizukami, A. Ishida et al., "Real-time loopmediated isothermal amplification for the CaMV-35S promoter as a screening method for genetically modified organisms," European Food Research and Technology, vol. 218, no. 5, pp. 496500, 2004.

[82] D. Lee, M. La Mura, T. R. Allnutt, and W. Powell, "Detection of genetically modified organisms (GMOs) using isothermal amplification of target DNA sequences," BMC Biotechnology, vol. 9, article 7, 2009.

[83] G. J. Randhawa, M. Singh, D. Morisset, P. Sood, and J. Žel, "Loop-mediated isothermal amplification: rapid visual and real-time methods for detection of genetically modified crops," Journal of Agricultural and Food Chemistry, vol. 61, no. 47, pp. 11338-11346, 2013.

[84] M. Zhang, Y. Liu, L. Chen et al., "One simple DNA extraction device and its combination with modified visual loop-mediated isothermal amplification for rapid on-field detection of genetically modified organisms," Analytical Chemistry, vol. 85, no. 1, pp. 75-82, 2013.

[85] C. Zahradnik, C. Kolm, R. Martzy et al., "Detection of the $35 \mathrm{~S}$ promoter in transgenic maize via various isothermal amplification techniques: a practical approach," Analytical and Bioanalytical Chemistry, vol. 406, no. 27, pp. 6835-6842, 2014.

[86] C. Wang, R. Li, S. Quan et al., "GMO detection in food and feed through screening by visual loop-mediated isothermal amplification assays," Analytical and Bioanalytical Chemistry, vol. 407, no. 16, pp. 4829-4834, 2015.

[87] Q. Li, J. Fang, X. Liu et al., "Loop-mediated isothermal amplification (LAMP) method for rapid detection of crylAb gene in transgenic rice (Oryza sativa L.)," European Food Research and Technology, vol. 236, no. 4, pp. 589-598, 2013.

[88] F. Li, W. Yan, L. Long, X. Qi, C. Li, and S. Zhang, "Development and application of loop-mediated isothermal amplification assays for rapid visual detection of $c r y 2 A b$ and $c r y 3 A$ genes in genetically-modified crops," International Journal of Molecular Sciences, vol. 15, no. 9, pp. 15109-15121, 2014.

[89] X. Huang, L. Chen, J. Xu, H.-F. Ji, S. Zhu, and H. Chen, "Rapid visual detection of phytase gene in genetically modified maize using loop-mediated isothermal amplification method," Food Chemistry, vol. 156, pp. 184-189, 2014.

[90] J. Xu, Q. Zheng, L. Yu et al., "Loop-mediated isothermal amplification (LAMP) method for detection of genetically modified maize T25," Food Science \& Nutrition, vol. 1, no. 6, pp. 432-438, 2013.

[91] Y. Cheng, M. Zhang, K. Hu et al., "Loop-mediated isothermal amplification for the event-specific detection of wheat B73-6-1," Food Analytical Methods, vol. 7, no. 2, pp. 500-505, 2014.
[92] A. Zimmermann, J. Lüthy, and U. Pauli, "Event specific transgene detection in Bt1l corn by quantitative PCR at the integration site," LWT-Food Science and Technology, vol. 33, no. 3, pp. 210-216, 2000.

[93] S. B. Rønning, M. Vaïtilingom, K. G. Berdal, and A. HolstJensen, "Event specific real-time quantitative PCR for genetically modified Bt11 maize (Zea mays)," European Food Research and Technology, vol. 216, no. 4, pp. 347-354, 2003.

[94] P. Windels, I. Taverniers, A. Depicker, E. Van Bockstaele, and M. De Loose, "Characterisation of the Roundup Ready soybean insert," European Food Research and Technology, vol. 213, no. 2, pp. 107-112, 2001.

[95] I. Taverniers, P. Windels, M. Vaïtilingom et al., "Event-specific plasmid standards and real-time PCR methods for transgenic Bt11, Bt176, and GA21 maize and transgenic GT73 canola," Journal of Agricultural and Food Chemistry, vol. 53, no. 8, pp. 3041-3052, 2005.

[96] P. Akritidis, K. Pasentsis, A. S. Tsaftaris, P. V. Mylona, and A. N. Polidoros, "Identification of unknown genetically modified material admixed in conventional cotton seed and development of an event-specific detection method," Electronic Journal of Biotechnology, vol. 11, no. 2, pp. 76-83, 2008.

[97] B. B. Majhi, J. M. Shah, and K. Veluthambi, "A novel T-DNA integration in rice involving two interchromosomal translocations," Plant Cell Reports, vol. 33, no. 6, pp. 929-944, 2014.

[98] Y. Cao, G. Wu, Y. Wu, S. Nie, L. Zhang, and C. Lu, "Characterization of the transgenic rice event TT51-1 and construction of a reference plasmid," Journal of Agricultural and Food Chemistry, vol. 59, no. 16, pp. 8550-8559, 2011.

[99] C. Su, J. Xie, X. Wang, and Y. Peng, "Integrated structure and event-specific real-time detection of transgenic crylAc/SCK rice Kefeng 6," European Food Research and Technology, vol. 232, no. 2, pp. 351-359, 2011.

[100] W.-X. Wang, T.-H. Zhu, F.-X. Lai, and Q. Fu, "Event-specific qualitative and quantitative detection of transgenic rice Kefeng8 by characterization of the transgene flanking sequence," European Food Research and Technology, vol. 234, no. 3, pp. 477484, 2012.

[101] M. H. Zhang, N. Huo, Y. Liu et al., "Event-specific detection of genetically modified wheat B73-6-1 based on the 3 '-flanking sequence," European Food Research and Technology, vol. 235, no. 6, pp. 1149-1159, 2012.

[102] M. Zhang, Y. Yu, X. Gao et al., "Event-specific quantitative detection of genetically modified wheat B72-8-11 based on the $3^{\prime}$ flanking sequence," European Food Research and Technology, vol. 240, no. 4, pp. 775-782, 2015.

[103] P. Zhang, J. Xu, Q. Zheng, F. Luan, J. Cao, and H. Hou, "Flanking sequence determination and event specific detection of transgenic wheat B72-8-11b strain," Applied Biochemistry and Biotechnology, vol. 169, no. 5, pp. 1523-1530, 2013.

[104] Q. Trinh, H. Shi, W. Xu, J. Hao, Y. Luo, and K. Huang, "Looplinker PCR: an advanced PCR technique for genome walking," IUBMB Life, vol. 64, no. 10, pp. 841-845, 2012.

[105] P. Windels, S. Bertrand, A. Depicker, W. Moens, E. Bockstaele, and M. Loose, "Qualitative and event-specific PCR real-time detection methods for StarLink maize," European Food Research and Technology, vol. 216, no. 3, pp. 259-263, 2003.

[106] P. Raymond, L. Gendron, M. Khalf et al., "Detection and identification of multiple genetically modified events using DNA insert fingerprinting," Analytical and Bioanalytical Chemistry, vol. 396, no. 6, pp. 2091-2102, 2010. 
[107] C. Collonnier, A. Schattner, G. Berthier et al., "Characterization and event specific-detection by quantitative real-time PCR of T25 maize insert," Journal of AOAC International, vol. 88, no. 2, pp. 536-546, 2005.

[108] A. Holck, M. Va, L. Didierjean, and K. Rudi, “ 5 '-Nuclease PCR for quantitative event-specific detection of the genetically modified Mon810 MaisGard maize," European Food Research and Technology, vol. 214, no. 5, pp. 449-453, 2002.

[109] R. Spalinskas, M. Van den Bulcke, G. Van den Eede, and A. Milcamps, "LT-RADE: an efficient user-friendly genome walking method applied to the molecular characterization of the insertion site of genetically modified maize MON810 and rice LLRICE62," Food Analytical Methods, vol. 6, no. 2, pp. 705713, 2013.

[110] R. Spalinskas, M. Van den Bulcke, and A. Milcamps, "Efficient retrieval of recombinant sequences of GM plants by Cauliflower Mosaic Virus 35S promoter-based bidirectional LT-RADE," European Food Research and Technology, vol. 237, no. 6, pp. 1025-1031, 2013.

[111] L. Yang, S. Xu, A. Pan et al., "Event specific qualitative and quantitative polymerase chain reaction detection of genetically modified MON863 maize based on the $5^{\prime}$-transgene integration sequence," Journal of Agricultural and Food Chemistry, vol. 53, no. 24, pp. 9312-9318, 2005.

[112] A. Pan, L. Yang, S. Xu et al., "Event-specific qualitative and quantitative PCR detection of MON863 maize based upon the $3^{\prime}$-transgene integration sequence," Journal of Cereal Science, vol. 43, no. 2, pp. 250-257, 2006.

[113] W.-X. Wang, T.-H. Zhu, F.-X. Lai, and Q. Fu, "Event-specific qualitative and quantitative detection of transgenic rice Kefeng6 by characterization of the transgene flanking sequence," European Food Research and Technology, vol. 232, no. 2, pp. 297305, 2011.

[114] J. Xu, J. Cao, D. Cao et al., "Flanking sequence determination and event-specific detection of genetically modified wheat B736-1," Acta Biochimica et Biophysica Sinica, vol. 45, no. 5, pp. 416421, 2013.

[115] R. Babekova, T. Funk, S. Pecoraro, K.-H. Engel, and U. Busch, "Development of an event-specific Real-time PCR detection method for the transgenic Bt rice line KMD1," European Food Research and Technology, vol. 228, no. 5, pp. 707-716, 2009.

[116] C. Liang, J. P. van Dijk, I. M. J. Scholtens et al., "Detecting authorized and unauthorized genetically modified organisms containing vip3A by real-time PCR and next-generation sequencing," Analytical and Bioanalytical Chemistry, vol. 406, no. 11, pp. 2603-2611, 2014.

[117] M.-A. Fraiture, P. Herman, I. Taverniers et al., "Validation of a sensitive DNA walking strategy to characterise unauthorised GMOs using model food matrices mimicking common rice products," Food Chemistry, vol. 173, pp. 1259-1265, 2015.

[118] M. A. Fraiture, P. Herman, L. Lefèvre et al., "Integrated DNA walking system to characterize a broad spectrum of GMOs in food/feed matrices," BMC Biotechnology, vol. 15, article 76, 2015.

[119] Q. Song, G. Wei, and G. Zhou, "Analysis of genetically modified organisms by pyrosequencing on a portable photodiode-based bioluminescence sequencer," Food Chemistry, vol. 154, pp. 7883, 2014.

[120] D. Kovalic, C. Garnaat, L. Guo et al., "The use of next generation sequencing and junction sequence analysis bioinformatics to achieve molecular characterization of crops improved through modern biotechnology," The Plant Genome, vol. 5, no. 3, pp. 149163, 2012.
[121] L. Young, J. Hammerlindl, V. Babic et al., "Genetics, structure, and prevalence of FP967 (CDC Triffid) T-DNA in flax," SpringerPlus, vol. 4, article 146, 2015.

[122] D. Wahler, L. Schauser, J. Bendiek, and L. Grohmann, "Nextgeneration sequencing as a tool for detailed molecular characterisation of genomic insertions and flanking regions in genetically modified plants: a pilot study using a rice event unauthorised in the EU," Food Analytical Methods, vol. 6, no. 6, pp. 1718-1727, 2013.

[123] L. Yang, C. Wang, A. Holst-Jensen, D. Morisset, Y. Lin, and D. Zhang, "Characterization of GM events by insert knowledge adapted re-sequencing approaches," Scientific Reports, vol. 3, article 2839, 2013.

[124] S. Willems, M. Fraiture, D. Deforce et al., "Statistical framework for detection of genetically modified organisms based on Next Generation Sequencing," Food Chemistry, vol. 192, pp. 788-798, 2016.

[125] A. Holst-Jensen, Y. Bertheau, M. de Loose et al., "Detecting un-authorized genetically modified organisms (GMOs) and derived materials," Biotechnology Advances, vol. 30, no. 6, pp. 1318-1335, 2012.

[126] T. Demeke and G. R. Jenkins, "Influence of DNA extraction methods, PCR inhibitors and quantification methods on realtime PCR assay of biotechnology-derived traits," Analytical and Bioanalytical Chemistry, vol. 396, no. 6, pp. 1977-1990, 2010.

[127] K. L. Opel, D. Chung, and B. R. McCord, "A study of PCR inhibition mechanisms using real time PCR," Journal of Forensic Sciences, vol. 55, no. 1, pp. 25-33, 2010.

[128] C. Schrader, A. Schielke, L. Ellerbroek, and R. Johne, "PCR inhibitors-occurrence, properties and removal," Journal of Applied Microbiology, vol. 113, no. 5, pp. 1014-1026, 2012.

[129] M. Van den Bulcke, A. Lievens, E. Barbau-Piednoir et al., "A theoretical introduction to 'combinatory SYBR Green qPCR Screening, a matrix-based approach for the detection of materials derived from genetically modified plants," Analytical and Bioanalytical Chemistry, vol. 396, no. 6, pp. 2113-2123, 2010.

[130] A. Block, F. Debode, L. Grohmann et al., "The GMOseek matrix: a decision support tool for optimizing the detection of genetically modified plants," BMC Bioinformatics, vol. 14, article 256, 2013.

[131] L. Gerdes, U. Busch, and S. Pecoraro, "GMOfinder-a GMO screening database," Food Analytical Methods, vol. 5, no. 6, pp. 1368-1376, 2012.

[132] JRC GMO-Amplicons, http://gmo-crl.jrc.ec.europa.eu/ jrcgmoamplicons/.

[133] A. Pla, V. Nadal, C. Baeten et al., "New multiplexing tools for reliable GMO detection," in Genetically Modified and NonGenetically Modified Food Supply Chains: Co-Existence and Traceability, pp. 333-366, Wiley, Oxford, UK, 2013.

[134] E. D. Vega and M. L. Marina, "Characterization and study of transgenic cultivars by capillary and microchip electrophoresis," International Journal of Molecular Sciences, vol. 15, no. 12, pp. 23851-23877, 2014.

[135] M. Milavec, D. Dobnik, L. Yang, D. Zhang, K. Gruden, and J. Žel, "GMO quantification: valuable experience and insights for the future," Analytical and Bioanalytical Chemistry, vol. 406, no. 26, pp. 6485-6497, 2014.

[136] H. I. Nakaya, E. M. Reis, and S. Verjovski-Almeida, "Concepts on microarray design for genome and transcriptome analyses," in Nucleic Acids Hybridization Modern Applications, pp. 265307, Springer, Dordrecht, The Netherlands, 2007. 
[137] D. Dobnik, D. Morisset, and K. Gruden, "NAIMA as a solution for future GMO diagnostics challenges," Analytical and Bioanalytical Chemistry, vol. 396, no. 6, pp. 2229-2233, 2010.

[138] F. Von Götz, "See what you eat-broad GMO screening with microarrays," Analytical and Bioanalytical Chemistry, vol. 396, no. 6, pp. 1961-1967, 2010.

[139] N. Shao, S.-M. Jiang, M. Zhang et al., "MACRO: a combined microchip-PCR and microarray system for high-throughput monitoring of genetically modified organisms," Analytical Chemistry, vol. 86, no. 2, pp. 1269-1276, 2014.

[140] Luminex, https://www.luminexcorp.com/.

[141] K. Fu, W. Huang, T. Deng, F. Li, H. Liu, and Y. Chen, "Multiplex PCR assay and liquid bead array for detection of 13 lines genetically modified maize," Journal of Chinese Institute of Food Science and Technology, vol. 15, no. 1, pp. 188-197, 2015.

[142] M. C. Strain, S. M. Lada, T. Luong et al., "Highly precise measurement of HIV DNA by droplet digital PCR," PLoS ONE, vol. 8, no. 4, Article ID e55943, 2013.

[143] M. Liu, Y. Luo, R. Tao et al., "Sensitive and rapid detection of genetic modified soybean (Roundup Ready) by loop-mediated isothermal amplification," Bioscience, Biotechnology and Biochemistry, vol. 73, no. 11, pp. 2365-2369, 2009.

[144] C. Leoni, M. Volpicella, F. De Leo, R. Gallerani, and L. R. Ceci, "Genome walking in eukaryotes," FEBS Journal, vol. 278, no. 21, pp. 3953-3977, 2011.

[145] I. Theuns, P. Windels, S. de Buck, A. Depicker, E. Van Bockstaele, and M. de Loose, "Identification and characterization of T-DNA inserts by T-DNA fingerprinting," Euphytica, vol. 123, no. 1, pp. 75-84, 2002.

[146] S. An, S. Park, D.-H. Jeong et al., "Generation and analysis of end sequence database for T-DNA tagging lines in rice," Plant Physiology, vol. 133, no. 4, pp. 2040-2047, 2003.

[147] A. Sallaud, D. Meynard, J. van Boxtel et al., "Highly efficient production and characterization of T-DNA plants for rice (Oryza sativa L.) functional genomics," Theoretical and Applied Genetics, vol. 106, no. 8, pp. 1396-1408, 2003.

[148] P. Windels, S. De Buck, E. Van Bockstaele, M. De Loose, and A. Depicker, "T-DNA integration in Arabidopsis chromosomes. Presence and origin of filler DNA sequences," Plant Physiology, vol. 133, no. 4, pp. 2061-2068, 2003.

[149] Y. Yuanxin, A. Chengcai, L. Li, G. Jiayu, T. Guihong, and C. Zhangliang, "T-linker-specific ligation PCR (T-linker PCR): an advanced PCR technique for chromosome walking or for isolation of tagged DNA ends," Nucleic acids research, vol. 31, no. 12 , article e68, 2003.

[150] C. Sallaud, C. Gay, P. Larmande et al., "High throughput T-DNA insertion mutagenesis in rice: a first step towards in silico reverse genetics," The Plant Journal, vol. 39, no. 3, pp. 450-464, 2004.

[151] H. Salvo-Garrido, S. Travella, L. J. Billiam, W. A. Harwood, and J. W. Snape, "The distribution of transgene insertion sites in barley determined by physical and genetic mapping," Genetics, vol. 167, no. 3, pp. 1371-1379, 2004.

[152] M.-J. Côté, A. J. Meldrum, P. Raymond, and C. Dollard, "Identification of genetically modified potato (Solanum tuberosum) cultivars using event specific polymerase chain reaction," Journal of Agricultural and Food Chemistry, vol. 53, no. 17, pp. 6691-6696, 2005.

[153] M. Rai, "Refinement of the Citrus tristeza virus resistance gene (Ctv) positional map in Poncirus trifoliata and generation of transgenic grapefruit (Citrus paradisi) plant lines with candidate resistance genes in this region," Plant Molecular Biology, vol. 61, no. 3, pp. 399-414, 2006.
[154] E. Santos, S. Remy, E. Thiry, S. Windelinckx, R. Swennen, and L. Sági, "Characterization and isolation of a T-DNA tagged banana promoter active during in vitro culture and low temperature stress," BMC Plant Biology, vol. 9, article 77, 2009.

[155] J. Ji and J. Braam, "Restriction site extension PCR: a novel method for high-throughput characterization of tagged DNA fragments and genome walking," PLoS ONE, vol. 5, no. 5, Article ID e10577, 2010.

[156] T. Ruttink, R. Demeyer, E. van Gulck et al., "Molecular toolbox for the identification of unknown genetically modified organisms," Analytical and Bioanalytical Chemistry, vol. 396, no. 6, pp. 2073-2089, 2010.

[157] D. Cullen, W. Harwood, M. Smedley, H. Davies, and M. Taylor, "Comparison of DNA walking methods for isolation of transgene-flanking regions in GM potato," Molecular Biotechnology, vol. 49, no. 1, pp. 19-31, 2011.

[158] A. Taheri, S. J. Robinson, I. Parkin, and M. Y. Gruber, "Revised selection criteria for candidate restriction enzymes in genome walking," PLoS ONE, vol. 7, no. 4, Article ID e35117, 2012.

[159] Q. Trinh, W. Xu, H. Shi, Y. Luo, and K. Huang, "An A-T linker adapter polymerase chain reaction method for chromosome walking without restriction site cloning bias," Analytical Biochemistry, vol. 425, no. 1, pp. 62-67, 2012.

[160] Q. L. Trinh, P. Zhu, H. Shi et al., "A-T linker adapter polymerase chain reaction for determining flanking sequences by rescuing inverse PCR or thermal asymmetric interlaced PCR products," Analytical Biochemistry, vol. 466, no. 1, pp. 24-26, 2014.

[161] G. N. Rudenko, C. M. T. Rommens, H. J. J. Nijkamp, and J. Hille, "Supported PCR: an efficient procedure to amplify sequences flanking a known DNA segment," Plant Molecular Biology, vol. 21, no. 4, pp. 723-728, 1993.

[162] S. Knapp, Y. Larondelle, M. Roßberg, D. Furtek, and K. Theres, "Transgenic tomato lines containing Ds elements at defined genomic positions as tools for targeted transposon tagging," MGG Molecular \& General Genetics, vol. 243, no. 6, pp. 666673, 1994.

[163] M. Devic, S. Albert, M. Delseny, and T. J. Roscoe, "Efficient PCR walking on plant genomic DNA," Plant Physiology and Biochemistry, vol. 35, no. 4, pp. 331-339, 1997.

[164] D. Spertini, C. Béliveau, and G. Bellemare, "Screening of transgenic plants by amplification of unknown genomic DNA flanking T-DNA," BioTechniques, vol. 27, no. 2, pp. 308-314, 1999.

[165] S. Balzergue, B. Dubreucq, S. Chauvin et al., "Improved PCRwalking for large-scale isolation of plant T-DNA borders," BioTechniques, vol. 30, no. 3, pp. 496-504, 2001.

[166] A. Cottage, A. Yang, H. Maunders, R. C. de Lacy, and N. A. Ramsay, "Identification of DNA sequences flanking T-DNA insertions by PCR-walking," Plant Molecular Biology Reporter, vol. 19, no. 4, pp. 321-327, 2001.

[167] S.-J. Zheng, B. Henken, E. Sofiari, E. Jacobsen, F. A. Krens, and C. Kik, "Molecular characterization of transgenic shallots (Allium cepa L.) by adaptor ligation PCR (AL-PRC) and sequencing of genomic DNA flanking T-DNA borders," Transgenic Research, vol. 10, no. 3, pp. 237-245, 2001.

[168] F. Samson, V. Brunaud, S. Balzergue et al., "FLAGdb/FST: a database of mapped flanking insertion sites (FSTs) of Arabidopsis thaliana T-DNA transformants," Nucleic Acids Research, vol. 30, no. 1, pp. 94-97, 2002.

[169] K. V. Myrick and W. M. Gelbart, "Universal Fast Walking for direct and versatile determination of flanking sequence," Gene, vol. 284, no. 1-2, pp. 125-131, 2002. 
[170] G. Tan, Y. Gao, M. Shi et al., "SiteFinding-PCR: a simple and efficient PCR method for chromosome walking," Nucleic Acids Research, vol. 33, no. 13, article e122, 2005.

[171] H. Wang, J. Fang, C. Liang, M. He, Q. Li, and C. Chu, "Computation-assisted sitefinding-PCR for isolating flanking sequence tags in rice," BioTechniques, vol. 51, no. 6, pp. 421-423, 2011.

[172] J.-L. Yao, S. Tomes, and A. P. Gleave, “Transformation of apple (Malus $\times$ domestica) using mutants of apple acetolactate synthase as a selectable marker and analysis of the T-DNA integration sites," Plant Cell Reports, vol. 32, no. 5, pp. 703-714, 2013.

[173] J. G. Bartlett, M. A. Smedley, and W. A. Harwood, "Analysis of T-DNA/host-plant DNA junction sequences in single-copy transgenic barley lines," Biology, vol. 3, no. 1, pp. 39-55, 2014.

[174] J. Ma, Y. P. Wang, S. Ren, Z. Zhang, S. Lu, and P. W. Wang, "Cloning flanking sequence by single-primer PCR in transgenic plants," Genetics and Molecular Research, vol. 13, no. 4, pp. 84038410, 2014.

[175] H. P. J. Buermans and J. T. den Dunnen, "Next generation sequencing technology: advances and applications," Biochimica et Biophysica Acta: Molecular Basis of Disease, vol. 1842, no. 10, pp. 1932-1941, 2014.

[176] H. Wu, W. Wu, Z. Chen et al., "Highly sensitive pyrosequencing based on the capture of free adenosine $5^{\prime}$ phosphosulfate with adenosine triphosphate sulfurylase," Analytical Chemistry, vol. 83, no. 9, pp. 3600-3605, 2011.

[177] PacBio, http://www.pacificbiosciences.com.

[178] L. Zhou and J. A. Holliday, "Targeted enrichment of the black cottonwood (Populus trichocarpa) gene space using sequence capture," BMC Genomics, vol. 13, article 703, 2012.

[179] A. J. Dubose, S. T. Lichtenstein, N. Narisu et al., "Use of microarray hybrid capture and next-generation sequencing to identify the anatomy of a transgene," Nucleic Acids Research, vol. 41, no. 6, article e70, 2013.

[180] W. E. Clarke, I. A. Parkin, H. A. Gajardo et al., "Genomic DNA enrichment using sequence capture microarrays: a novel approach to discover sequence nucleotide polymorphisms (SNP) in Brassica napus L," PLoS ONE, vol. 8, no. 12, Article ID e81992, 2013.

[181] M. G. Dasgupta, V. Dharanishanthi, I. Agarwal, K. V. Krutovsky, and S. K. Parida, "Development of genetic markers in eucalyptus species by target enrichment and exome sequencing," PLoS ONE, vol. 10, no. 1, Article ID e0116528, 2015.

[182] M. C. Schatz, J. Witkowski, and W. R. McCombie, "Current challenges in de novo plant genome sequencing and assembly," Genome Biology, vol. 13, no. 4, article 243, 2012.

[183] K. F. Au, J. G. Underwood, L. Lee, and W. H. Wong, "Improving PacBio long read accuracy by short read alignment," PLOS ONE, vol. 7, no. 10, Article ID e46679, 2012. 

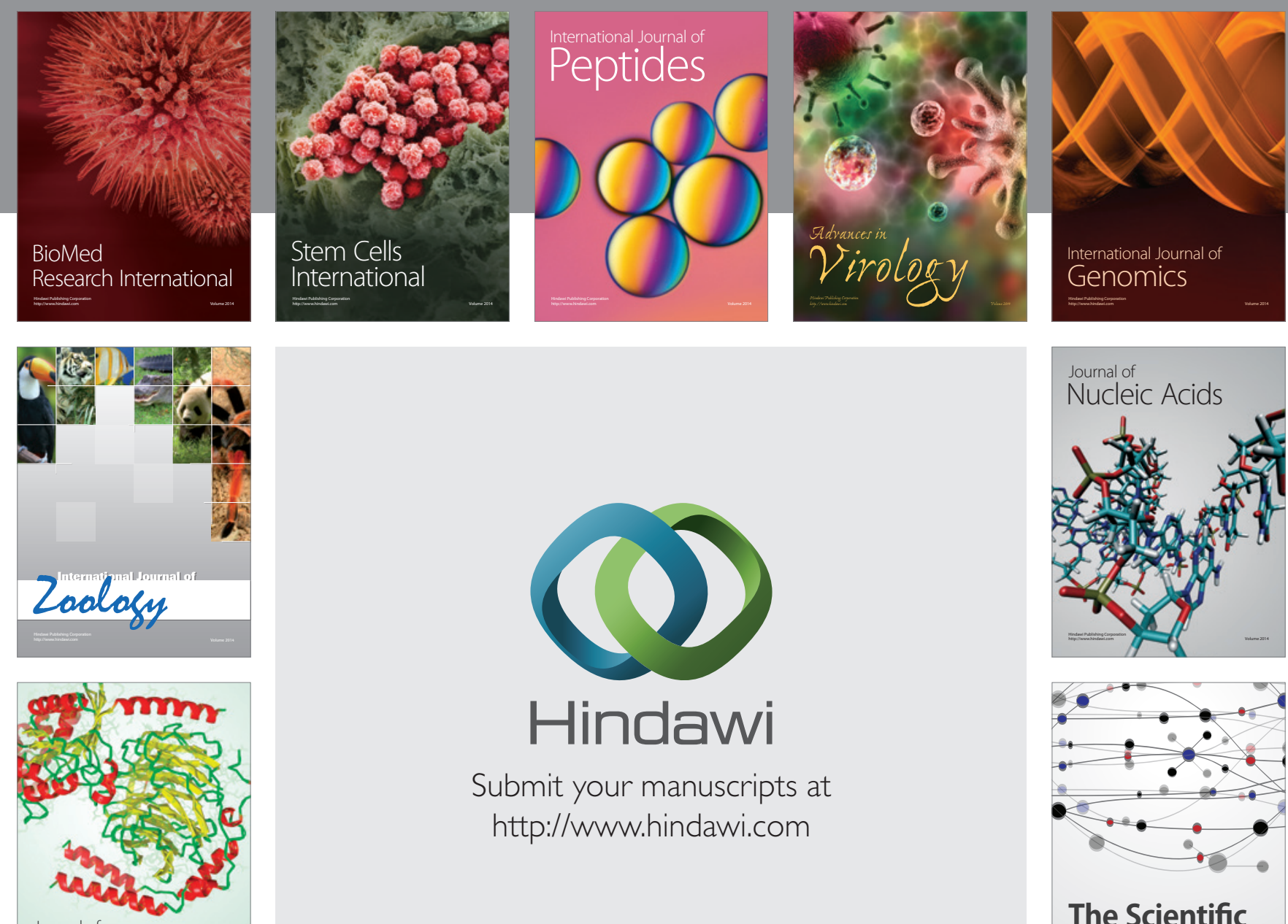

Submit your manuscripts at

http://www.hindawi.com

Journal of
Signal Transduction
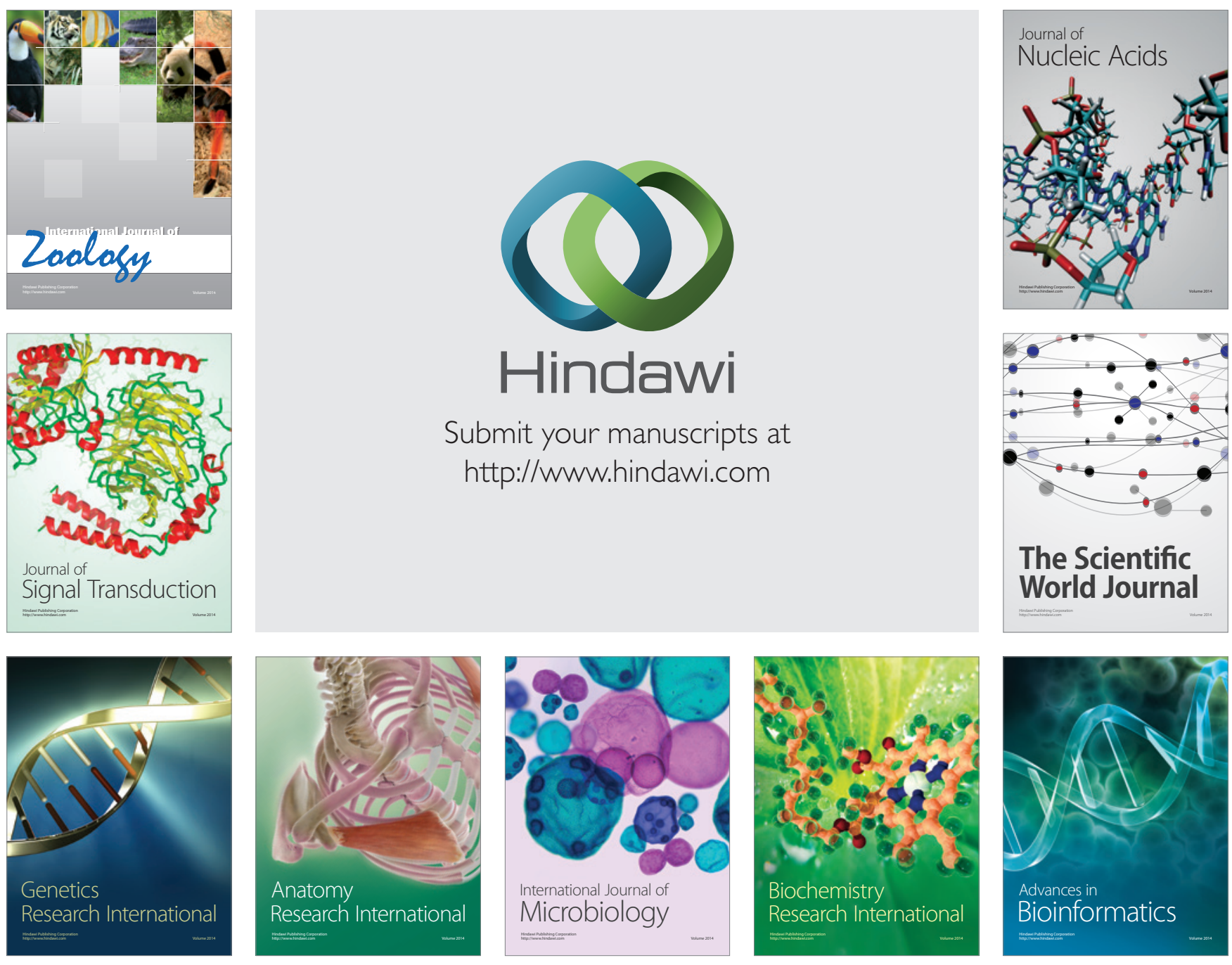

The Scientific World Journal
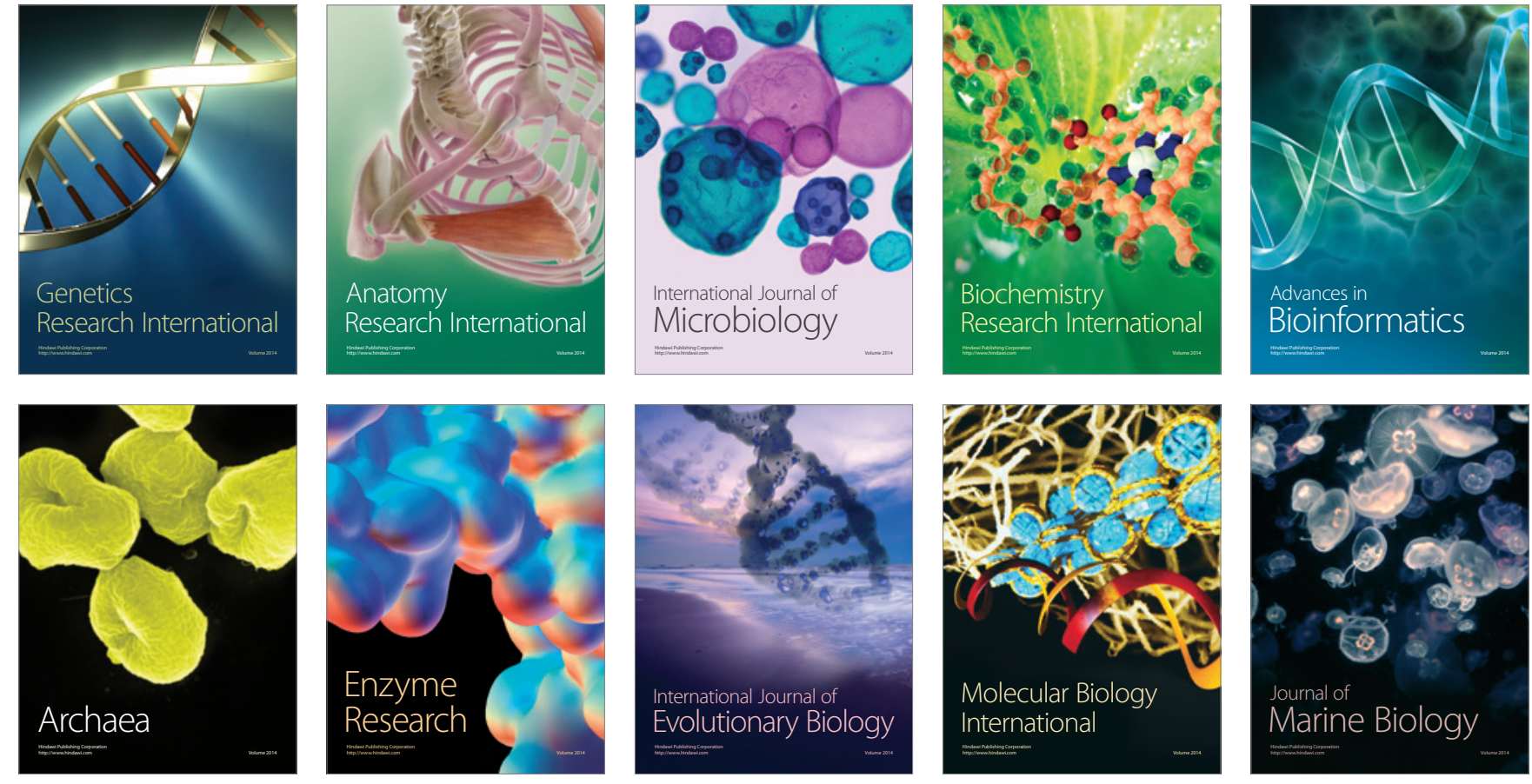